\title{
CD44 Signaling Mediates High Molecular Weight Hyaluronan-Induced Antihyperalgesia
}

\author{
ㄴuz F. Ferrari, Eugen V. Khomula, Dioneia Araldi, and $\$ Jon D. Levine \\ Departments of Medicine and Oral Surgery, and Division of Neuroscience, University of California at San Francisco, San Francisco, California 94143
}

We studied, in male Sprague Dawley rats, the role of the cognate hyaluronan receptor, CD44 signaling in the antihyperalgesia induced by high molecular weight hyaluronan (HMWH). Low molecular weight hyaluronan (LMWH) acts at both peptidergic and nonpeptidergic nociceptors to induce mechanical hyperalgesia that is prevented by intrathecal oligodeoxynucleotide antisense to CD44 mRNA, which also prevents hyperalgesia induced by a CD44 receptor agonist, A6. Ongoing LMWH and A6 hyperalgesia are reversed by HMWH. HMWH also reverses the hyperalgesia induced by diverse pronociceptive mediators, prostaglandin $\mathrm{E}_{2}$, epinephrine, $\mathrm{TNF} \alpha$, and interleukin-6, and the neuropathic pain induced by the cancer chemotherapy paclitaxel. Although CD44 antisense has no effect on the hyperalgesia induced by inflammatory mediators or paclitaxel, it eliminates the antihyperalgesic effect of HMWH. HMWH also reverses the hyperalgesia induced by activation of intracellular second messengers, $\mathrm{PKA}$ and $\mathrm{PKC}_{\varepsilon}$, indicating that $\mathrm{HMWH}$-induced antihyperalgesia, although dependent on CD44, is mediated by an intracellular signaling pathway rather than as a competitive receptor antagonist. Sensitization of cultured small-diameter DRG neurons by prostaglandin $\mathrm{E}_{2}$ is also prevented and reversed by HMWH. These results demonstrate the central role of CD44 signaling in HMWH-induced antihyperalgesia, and establish it as a therapeutic target against inflammatory and neuropathic pain.

Key words: CD44; extracellular matrix; hyaluronan; hyperalgesia; nociceptor

Significance Statement

We demonstrate that hyaluronan (HA) with different molecular weights produces opposing nociceptive effects. While low molecular weight HA increases sensitivity to mechanical stimulation, high molecular weight HA reduces sensitization, attenuating inflammatory and neuropathic hyperalgesia. Both pronociceptive and antinociceptive effects of $\mathrm{HA}$ are mediated by activation of signaling pathways downstream CD44, the cognate HA receptor, in nociceptors. These results contribute to our understanding of the role of the extracellular matrix in pain, and indicate CD44 as a potential therapeutic target to alleviate inflammatory and neuropathic pain.

\section{Introduction}

Tissue injury affects cell function by producing changes in the extracellular environment (Padmanabhan and Gonzalez, 2012). Inflammation-induced alterations in the extracellular matrix (ECM), a complex cell scaffold composed of proteins, elastins, glycoproteins (laminins and fibronectins), and proteoglycans (Carulli et al., 2005; Soleman et al., 2013), have been demonstrated to contribute to changes in neuronal function (Komori et al., 2004; Kozai et al., 2007; Agrawal et al., 2008; Padmanabhan and Gon-

Received Sept. 18, 2017; revised Nov. 8, 2017; accepted Nov. 13, 2017.

Author contributions: L.F.F., E.V.K., and J.D.L. designed research; L.F.F., E.V.K., and D.A. performed research; L.F.F. and E.V.K. analyzed data; L.F.F., E.V.K., and J.D.L. wrote the paper.

This work was supported by National Institutes of Health Grant NS084545.

The authors declare no competing financial interests.

Correspondence should be addressed to Dr. Jon D. Levine, University of California-San Francisco, 521 Parnassus Avenue, San Francisco, CA 94143-0440. E-mail: jon.levine@ucs.edu.

DOI:10.1523/JNEUROSCI.2695-17.2017

Copyright $\odot 2018$ the authors $\quad 0270-6474 / 18 / 380308-14 \$ 15.00 / 0$ zalez, 2012; Gaudet and Popovich, 2014; Tajerian and Clark, 2015). We recently provided evidence that the glycosaminoglycan, hyaluronic acid [hyaluronan (HA)], a major ECM component (Juhlin, 1997; Buhren et al., 2016), modulates nociceptor function in the setting of inflammation (Ferrari et al., 2016a). The production of low molecular weight $\mathrm{HA}(\mathrm{LMWH})$ from high molecular weight HA (HMWH), by the enzyme hyaluronidase, in the inflammatory process (Monzon et al., 2010; Campo et al., 2012), has been shown to impact nociceptor sensitivity to mechanical stimulation (Ferrari et al., 2016a). In this regard, CD44, a ubiquitously expressed transmembrane protein (Basakran, 2015; Senbanjo and Chellaiah, 2017), considered the cognate HA receptor (Goodison et al., 1999; Bourguignon et al., 2014), has been proposed to mediate the effects of HA on nociceptors (Ferrari et al., 2016a).

CD44 participates in many physiological and pathological processes (Dzwonek and Wilczynski, 2015), including axonal guidance during neuronal development (Sretavan et al., 1994; Ries et al., 2007) 
and degeneration (Gorlewicz et al., 2009) and synaptic plasticity and memory (Gorlewicz et al., 2009; Raber et al., 2014). In addition, studies showing upregulation of CD44 in both neuronal and non-neuronal cells, after trauma (Jones et al., 2000; Shin et al., 2005), indicate a regulatory role of CD44 in cellular response to inflammation.

We previously demonstrated that local injection of either hyaluronidase, an enzyme that metabolizes HMWH to LMWH, or LMWH, induces mechanical hyperalgesia (Ferrari et al., 2016a). LMWH-induced hyperalgesia was attenuated by A5G27, a peptide that binds to and inhibits CD44-dependent signaling (Hibino et al., 2004; Pesarrodona et al., 2014), suggesting that CD44 is a receptor at which LMWH acts to induce hyperalgesia. Pretreatment with HMWH also prevented LMWH hyperalgesia, compatible with opposing effects of HA, dependent on its molecular weight. These observations raise the question: how do LMWH and HMWH act at CD44, the cognate HA receptor (Underhill, 1992; Bajorath et al., 1998; Teriete et al., 2004), to produce pronociceptive and antinociceptive effects, respectively? Our results point to a receptor-mediated effect of HMWH on nociceptors that contrast with conclusions of previous studies that attributed the therapeutic effect of HMWH for pain associated with osteoarthritis (Dougados et al., 1993; Altman and Moskowitz, 1998; Cohen et al., 2008; Triantaffilidou et al., 2013) to its viscoelastic properties (Radin et al., 1970; Unsworth et al., 1975; Mabuchi et al., 1994; Elmorsy et al., 2014; Cowman et al., 2015).

In this study, we demonstrate that CD44 is the main nociceptor receptor that mediates the opposing nociceptive effects of LMWH and HMWH, establishing CD44 as a target with therapeutic relevance for the treatment of pain associated with osteoarthritis and potentially other pain syndromes.

\section{Materials and Methods}

Animals. Experiments were performed on 220-400 g male Sprague Dawley rats (Charles River Laboratories). Rats were housed 3 per cage, under a $12 \mathrm{~h}$ light/dark cycle, in a temperature- and humidity-controlled room in the animal care facility of the University of California, San Francisco. Food and water were available ad libitum. Experimental protocols were approved by the Institutional Animal Care and Use Committee at the University of California, San Francisco, and adhered to the National Institutes of Health Guidelines for the care and use of laboratory animals. Every effort was made to minimize the number of animals used and their suffering.

Testing mechanical nociception. Nociceptive testing was performed between 10:00 A.M. and 5:00 P.M. Mechanical nociceptive threshold was quantified using an Ugo Basile Analgesymeter to perform the Randall-Selitto paw withdrawal test (Stoelting). The analgesymeter applies a linearly increasing mechanical force to the dorsum of the rat's hindpaw, as previously described (Randall and Selitto, 1957; Taiwo and Levine, 1989; Taiwo et al., 1989). Nociceptive threshold was defined as the force in grams at which the rat withdrew its paw. Baseline paw-pressure threshold was defined as the mean of the three readings taken before a test agent was injected. Each experiment was performed on a different group of rats. Data are presented as the mean change from baseline nociceptive threshold.

Drug administration. The following drugs were used in this study: hyaluronic acid sodium salt from Streptococcus pyrogenes (HMWH), from Calbiochem; epinephrine, prostaglandin $\mathrm{E}_{2}\left(\mathrm{PGE}_{2}\right)$, hyaluronic acid sodium salt from Streptococcus equi (LMWH), and the cancer chemotherapeutic agent paclitaxel, from Sigma-Aldrich; a peptide CD44 receptor agonist A6 (Piotrowicz et al., 2011; Finlayson, 2015) from GenScript; rat recombinant interleukin-6 (IL-6) and rat recombinant TNF $\alpha$, from R\&D Systems; the selective activator of PKC $\varepsilon$, psi $\varepsilon$ Receptor for Activated C Kinase ( $\psi \varepsilon$ RACK), from Biomatik; and the potent membranepermeable cAMP analog 8-bromo cAMP sodium salt (Tocris Bioscience). Drug doses were selected based on our previous studies (Taiwo and Levine, 1991; Aley et al., 2000; Dina et al., 2001, 2008; Parada et al., 2003a; Ferrari et al., 2015a, 2016b). Stock solutions of $\mathrm{PGE}_{2}$, dissolved in abso- lute ethanol to a concentration of $1 \mu \mathrm{g} / \mu \mathrm{l}$, were further diluted in saline (1:50, final concentration $0.2 \mu \mathrm{g} / \mu \mathrm{l}$ ) immediately before experiments. The ethanol concentration of the final $\mathrm{PGE}_{2}$ solution was $\sim 2 \%$, a concentration previously shown to not affect mechanical nociceptive threshold (Ferrari et al., 2016b). Epinephrine was dissolved in saline in a solution containing ascorbic acid, in a proportion 1:1, immediately before injection; the control solution, containing only ascorbic acid in saline, does not affect mechanical nociceptive threshold (Khasar et al., 1999). Aliquots of HMWH, LMWH, A6, IL-6, or $\psi \varepsilon$ RACK, dissolved in distilled water to a concentration of $1 \mu \mathrm{g} / \mu \mathrm{l}$, were diluted in saline to the desired concentration at the time of the experiment. 8-Bromo cAMP was dissolved in distilled water and diluted in saline immediately before injection; TNF $\alpha$ was first dissolved in PBS containing $0.1 \%$ BSA, then diluted in saline before administration. All drugs, except paclitaxel, were administered intradermally, in a volume of $5 \mu \mathrm{l}$, on the dorsum of the hindpaw, using a 30-gauge beveled hypodermic needle attached to a 50 $\mu \mathrm{l}$ microsyringe (Hamilton) by a short length of polyethylene (PE-10) tubing. The administration of $\psi \varepsilon$ RACK was preceded by a hypotonic shock induced by distilled water, to increase cell permeability $(1 \mu \mathrm{l}$ of distilled water, separated by a bubble of air to avoid mixing in the same syringe) and to facilitate movement of compounds across the plasma membrane of the nociceptor, into the cytoplasm of the peripheral terminal (Borle and Snowdowne, 1982; Burch and Axelrod, 1987).

Paclitaxel, dissolved in absolute ethanol and polyethoxylated castor oil (Cremophor EL; 1:1) (Apfel et al., 1991; Adams et al., 1993; Cavaletti et al., 1995; Cliffer et al., 1998), diluted in saline to a concentration of 1 $\mathrm{mg} / \mathrm{ml}$ just before injection, was administered intraperitoneally (Hamers et al., 1993; Cavaletti et al., 1997) in a dose of $1 \mathrm{mg} / \mathrm{kg}$, once every other day for 4 doses. This protocol has been previously shown to produce a preclinical model of chemotherapy-induced painful peripheral neuropathy (Dina et al., 2001; Alvarez et al., 2011).

Deletion of peptidergic and nonpeptidergic nociceptors. To determine which subtype of nociceptor, peptidergic or nonpeptidergic, is involved in the mechanical hyperalgesia induced by LMWH, rats were pretreated with neurotoxins previously shown to selectively deplete these two types of sensory neurons: isolectin B4 (IB4)-saporin, which acts on IB4 ${ }^{+}$, nonpeptidergic neurons (Vulchanova et al., 2001; Nishiguchi et al., 2004; Joseph et al., 2008), and [Sar9,Met $\left.\left(\mathrm{O}_{2}\right) 11\right]$ substance P-saporin (SSPsaporin), shown to deplete peptidergic fibers (Khasabov et al., 2002; Vierck et al., 2003; Wiley et al., 2007; Choi et al., 2012; Weisshaar and Winkelstein, 2014). Both IB4-saporin and SSP-saporin (from Advanced Targeting Systems) were diluted in saline to doses previously shown to deplete nonpeptidergic ( $3.2 \mu \mathrm{g} / \mathrm{rat}$ for IB4-saporin) and peptidergic (100 ng/rat for SSP-saporin) fibers (Vulchanova et al., 2001; Wiley et al., 2007; Choi et al., 2012). The toxins were administered intrathecally, in a volume of $20 \mu \mathrm{l}, 14 \mathrm{~d}$ before the intradermal injection of LMWH on the dorsum of the hindpaw.

For intrathecal injections, rats were briefly anesthetized with $2.5 \%$ isoflurane (Phoenix Pharmaceuticals) in $97.5 \% \mathrm{O}_{2}$. Then, a 30-gauge hypodermic needle was inserted, on the midline, into the subarachnoid space, between the L4 and L5 vertebrae. The control treatment consisted of intrathecal injection of saline (vehicle, $20 \mu \mathrm{l}$ ). Animals regained consciousness $\sim 1 \mathrm{~min}$ after removal from the anesthetic chamber. Of note, treatment with IB4-saporin, SSP-saporin, or their combination did not significantly affect mechanical nociceptive threshold. Also, in the group treated with both toxins, each was injected separately at different times on the same day, to avoid drug interaction or spinal cord damage induced by the injection of a large volume.

Oligodeoxynucleotide (ODN) antisense to CD44 mRNA. To assess the role of CD44 in mechanical hyperalgesia induced by LMWH, the CD44 agonist A6, inflammatory mediators, or the neurotoxic chemotherapy agent paclitaxel, rats were treated with an ODN antisense to CD44 mRNA, previously shown to decrease CD44 protein expression (Lamb et al., 1997). The antisense ODN sequence to CD44 mRNA, 5'-GAA AAG GGT CGC GGG GG-3', synthesized by Invitrogen, was directed against a unique region of the rat CD44 mRNA sequence (GenBank number NM_012924). The ODN sense sequence, shown to not produce any effect on the expression of CD44 (Lamb et al., 1997), used as control, was 5'-CCC CCG CGA CCC TTT TC-3'. A search of the National Center for 
Biotechnology Information database to Rattus norvegicus identified no other homologous sequences. Before use, the ODNs were lyophilized and then reconstituted in saline to a desired concentration $(2,4$, or $6 \mu \mathrm{g} / \mu \mathrm{l})$, and a volume of $20 \mu \mathrm{l}$ containing 40,80 , or $120 \mu \mathrm{g}$ of ODN was slowly injected intrathecally, as described above for treatment with IB4-saporin and/or SSP-saporin. ODN injections were performed once a day, for 3 consecutive days, a protocol previously demonstrated to be sufficient to impact the expression of multiple proteins in nociceptors, important for sensitization (Parada et al., 2003b; Song et al., 2009; Su et al., 2011; Bogen et al., 2012; Quanhong et al., 2012; Sun et al., 2013).

Preparation of DRG neuron cultures. Primary cultures of rat DRG sensory neurons were obtained from adult males and prepared as previously described (Hendrich et al., 2013; Ferrari et al., 2016b; Khomula et al., 2017). In brief, under isoflurane anesthesia, rats were decapitated, the dorsum of the vertebral column opened, and the fourth and fifth lumbar DRGs rapidly removed, and chilled in cold HBSS. The DRGs were then treated with $0.125 \%$ collagenase $\mathrm{P}$ (Worthington Biochemical) in HBSS for $90 \mathrm{~min}$ at $37^{\circ} \mathrm{C}$, and treated with $0.25 \%$ trypsin (Worthington Biochemical) in calcium- and magnesium-free PBS (Invitrogen) for $10 \mathrm{~min}$, followed by 3 times washout and trituration in Neurobasal-A medium (Invitrogen) to produce a single-cell suspension. The suspension was centrifuged at 1000 RPM for 3 min and resuspended in Neurobasal-A medium supplemented with $50 \mathrm{ng} / \mathrm{ml}$ nerve growth factor, $100 \mathrm{U} / \mathrm{ml}$ penicillin/ streptomycin, and B-27 (Invitrogen). Cells were then plated on coverslips and incubated at $37^{\circ} \mathrm{C}$ in $5 \% \mathrm{CO}_{2}$ for at least $24 \mathrm{~h}$ before use.

Microscopy and fluorescent imaging. The bright-field imaging system consisted of an inverted microscope (Eclipse TE-200, Nikon) with epifluorescence using a xenon lamp (Lambda LS, Sutter Instruments) for excitation. Illumination was controlled by a Lambda 10-2 filter wheel controller and Lambda SC Smart Shutter controller (Sutter Instruments); an Andor Clara Interline CCD camera (Andor Technology) was used for high-resolution digital image acquisition. MetaFluor software (Molecular Devices) provided computer interface and controlled the whole system as well as being used for image processing. A Plan Fluor objective (20× UV, NA 0.50; Nikon) was used for both fluorescent and transmitted light imaging with phase contrast.

Histochemistry. Cells were incubated in Tyrode's solution supplemented with $10 \mu \mathrm{g} / \mathrm{ml} \mathrm{IB} 4$ conjugated to AlexaFluor-488 dye (Invitrogen) for 10-12 min in the dark. After washout, the fluorescent images were captured during the first $15 \mathrm{~min}$ of each experiment using a standard GFP filter set (Chroma Technology). Cells demonstrating bright fluorescence and halo around the neuronal plasma were recognized as IB4 $4^{+}$, whereas those having intensity $<20 \%$ of maximum for selected field of view were considered as IB4 ${ }^{-}$.

In vitro electrophysiology. The electrophysiological recordings from the DRG cultures were performed between 24 and $96 \mathrm{~h}$ after dissociation and plating. At least 3 rats/culture preparation were used for each experimental series. Within the text, " $n$ " refers to the number of neurons. Cells were identified as neurons by having double birefringent plasma membranes (Cohen et al., 1968; Landowne, 1993) and the ability to generate action potentials (APs). While small-, medium-, and large-sized neurons were routinely observed in the same preparation, this study was focused only on cells with a soma diameter $<45 \mu \mathrm{m}$ (small and medium DRG neurons, predominantly representing the $\mathrm{C}$ - and $\mathrm{A} \delta$-type nociceptor subpopulation). After neurons were placed in the recording chamber, the culture medium was replaced with Tyrode's solution containing $140 \mathrm{~mm}$ $\mathrm{NaCl}, 4 \mathrm{~mm} \mathrm{KCl}, 2 \mathrm{~mm} \mathrm{MgCl}$, $2 \mathrm{~mm} \mathrm{CaCl}_{2}, 10 \mathrm{~mm}$ glucose, $10 \mathrm{~mm}$ HEPES, adjusted to pH 7.4 with $\mathrm{NaOH}, 310$ mOsm. Tyrode's solution was used in the further in vitro experiments as external perfusion solution; and all fluorescent dyes and stimulating and modulating drugs were applied diluted in this solution. The perfusion system was gravity-driven at a flow rate of $0.5-1 \mathrm{ml} / \mathrm{min}$. All experiments were performed at room temperature, $20^{\circ} \mathrm{C}-23^{\circ} \mathrm{C}$.

Whole-cell patch-clamp recordings in current-clamp mode were made to assess changes in the excitability of cultured DRG neurons by modification/adjustment of commonly used previously established protocols (Hendrich et al., 2013; Duzhyy et al., 2015; Saloman et al., 2016; Viatchenko-Karpinski and Gu, 2016).
Recording electrodes were fabricated from borosilicate glass capillaries (0.84/1.5 mm i.d./o.d., Warner Instruments) using a Flaming/Brown P-87 puller (Sutter Instruments). The recording electrode resistance was $\sim 5 \mathrm{M} \Omega$ after being filled with solution containing the following (in $\mathrm{mm}$ ): $130 \mathrm{KCl}, 10 \mathrm{HEPES}, 10 \mathrm{EGTA}, 1 \mathrm{CaCl}_{2}, 5 \mathrm{MgATP}$, and $1 \mathrm{Na}-\mathrm{GTP}, \mathrm{pH} 7.2$ (adjusted with Tris-base), 300 mOsm (measured by Wescor Vapro 5520 osmometer, ELITech Group). The junction potential was not adjusted. The series resistance was $<20 \mathrm{~m} \Omega$ at the end of recordings and was not compensated. Recordings were made with an Axon MultiClamp $700 \mathrm{~B}$ amplifier, filtered at $10 \mathrm{kHz}$, and sampled at $20 \mathrm{kHz}$ using Axon Digidata 1550B controlled by pCLAMP 10 software (all from Molecular Devices).

Holding current (in current-clamp mode) was adjusted to maintain membrane potential at $-70 \mathrm{mV}$. Capacitance, membrane input, and series ("access") resistances were estimated before and 3-5 and $10 \mathrm{~min}$ after the application of drugs with the aid of amplifier circuitry (during a short switch to voltage-clamp mode).

Drugs (LMWH and HMWA, $0.2 \mathrm{mg} / \mathrm{ml}$, equivalent to $1 \mu \mathrm{g} / 5 \mu \mathrm{l}$, as used in the behavioral experiments, and $\mathrm{PGE}_{2}, 1 \mu \mathrm{M}$ ) were applied at least $10 \mathrm{~min}$ after the establishment of whole-cell configuration to achieve equilibrium. Drug-induced changes in AP generation were assessed via several protocols that were repeated in series every $30 \mathrm{~s}$ to $3 \mathrm{~min}$ to monitor various passive and active electrophysiological properties over time.

Active electrophysiological properties, such as rheobase (minimum magnitude of current step to elicit an AP) and AP threshold potential, were determined from a protocol using increasing square wave current pulses. Initially starting from $-50 \mathrm{pA}$ with $200 \mathrm{pA}$ step to determine rheobase roughly, protocol was then adjusted to 5-6 pulses with step size of $5 \%-10 \%$ of rheobase (2-3 subthreshold stimulations and $2-3$ with AP generation to achieve reasonable precision and to avoid overstimulation/ desensitization) and applied every 3 min.

AP threshold potential was determined from approximation of the initial part of response to square pulse of rheobase magnitude (inducing AP) with sum of decaying and rising exponents, representing membrane capacitance recharge and initial rising part of AP development (Duzhyy et al., 2015; Viatchenko-Karpinski and Gu, 2016). Decaying component of the fit was then subtracted from the original recording and result represented "AP component." We considered that AP threshold potential was achieved when "AP component" raised above the arbitrary selected value of $2 \mathrm{mV}$, representing sensitivity of the definition. Potential on the original recording corresponding to that point was manifested as AP threshold potential.

AP overshoot (peak, measured from $0 \mathrm{mV}$ ), duration of rising and decaying phases (time of 10\%-90\% rise/fall from base to peak), minimum of afterhyperpolarization (AHP, "antipeak," measured from $0 \mathrm{mV}$ ), half-width (at halfway from peak to antipeak), were assessed every $30 \mathrm{~s}$ from APs elicited by step current fixed at $120 \%-140 \%$ of baseline rheobase (constant over time).

The following electrophysiological properties were assessed with an AP evoked by a short (1-3 ms) depolarizing current pulse: AP overshoot, duration at base (at level of the $V_{\mathrm{m}}$ ), magnitude of the AHP measured from the $V_{\mathrm{m}}$, and AHP decay time ( $\tau$ AHP) from the fit with a single exponential function.

Ramp protocol consisted of ramp current pulse with duration from 200 to $500 \mathrm{~ms}$ and slope factor from 0.2 to $4 \mathrm{pA} / \mathrm{ms}$. Neurons were repeatedly stimulated every 1-3 min. Latency of the peak of the first AP was used to characterize effect of $\mathrm{HMWH}$ on $\mathrm{PGE}_{2}$-induced sensitization.

Statistical analysis. In all behavioral experiments, the dependent variable was paw withdrawal threshold, expressed as percentage change from baseline. We used 150 rats (300 paws) in the behavioral tests. The average paw withdrawal threshold before the experiments was $123.90 \pm 3.1 \mathrm{~g}$. To compare the changes in the nociceptive threshold induced by the injection of a hyperalgesic agent in control groups with the groups treated with $\mathrm{HMWH}$ or CD44 antisense, repeated-measures (see Figs. 1, 4A), one-way (see Fig. 3) or two-way (see Fig. 4A) ANOVA, followed by Bonferroni post hoc test, or Student's $t$ test (see Figs. 2, 3, 4B, C, 5, 6), was used. The injection of HMWH alone, or the vehicles used to dissolve the drugs, did not produce a change in the mechanical threshold (data not shown).

For the electrophysiological experiments, drug (LMWH, HMWH, and/or $\mathrm{PGE}_{2}$ )-induced changes were also analyzed as a percentage (rela- 


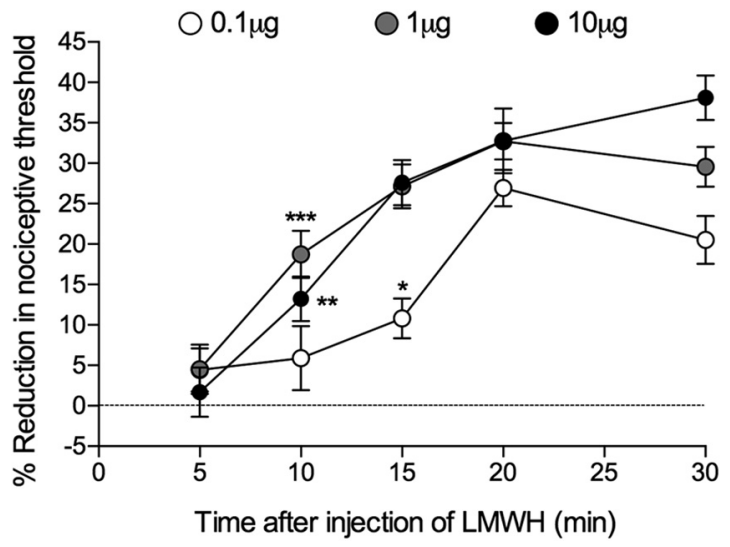

Figure 1. Dose- and time-effect relationships for LMWH-induced mechanical hyperalgesia. Mechanical nociceptive threshold was evaluated before and 5, 10, 15, 20, and 30 min after intradermal injection of LMWH $(0.1,1$, or $10 \mu \mathrm{g})$ on the dorsum of the hindpaw, in separate groups of rats. All three doses induced robust mechanical hyperalgesia ( $0.1 \mu \mathrm{g}$ group: $F_{(2.164,10.82)}=14.69, p=0.0007 ; 1 \mu \mathrm{g}$ group: $F_{(2.366,11.83)}=38.95, p<0.0001 ; 10 \mu \mathrm{g}$ group: $\left.F_{(1.968,9.839)}=30.07, p<0.0001\right)$ when the mechanical nociceptive threshold over time is compared with pre-LMWH injection baseline (repeated-measures ANOVA, followed by Bonferroni post hoc test). For the $0.1 \mu \mathrm{g}$ dose, hyperalgesia was significant starting 15 min after injection ${ }^{*} p=0.0062$, when the mechanical threshold at this time point is compared with baseline). For the 1 and $10 \mu \mathrm{g}$ doses, the hyperalgesia was already significant by $10 \min (1 \mu \mathrm{g}$, $\left.{ }^{* * *} p=0.0010 ; 10 \mu g,{ }^{* *} p=0.0060\right) . n=6$ paws per group.

tive) change from baseline, to facilitate comparisons between DRG neurons, known to be highly heterogeneous even within specific subgroups (i.e., small/medium, IB4 ${ }^{+}$or IB4 ${ }^{-}$), allowing the use of paired comparisons, to minimize the effect of high variability of initial (baseline) values of parameters (sometimes up to $60 \%$ of mean). Comparison of the relative change to 0 by Student's $t$ test (always two-tailed) was used to establish the effect in a single group. Two groups were compared with use of unpaired Student's $t$ test for unequal variances (with Welch correction), whereas ANOVA followed by Bonferroni or Dunnett's post hoc test was used for multiple comparisons. At least three measurements of each parameter analyzed were used to establish the stability of neuronal excitability before the application of drugs (i.e., baseline). The magnitude of the effect was assessed typically after $10 \mathrm{~min}$ of exposure to the drug.

Prism 6.0 (GraphPad Software) was used for the graphics and to perform statistical analyses; $p<0.05$ was considered statistically significant. Data are presented as mean \pm SEM.

\section{Results}

\section{LMWH induces mechanical hyperalgesia}

To characterize the pronociceptive effect of LMWH, in separate groups of rats, we evaluated the time course of the hyperalgesia induced by three doses of LMWH $(0.1,1$, and $10 \mu \mathrm{g})$. Hyperalgesia induced by 1 and $10 \mu \mathrm{g}$ was present by $10 \min (p=0.0010$ and $p=0.0060$, respectively), whereas that induced by $0.1 \mu \mathrm{g}$ was not significant until $15 \mathrm{~min}$ after injection $(p=0.0062$, when the mechanical thresholds at those time points are compared with pre-LMWH levels) (Fig. 1). Based on these findings, the $1 \mu \mathrm{g}$ dose and 30 min postinjection time point, when peak hyperalgesia was established, were chosen to evaluate the effect of LMWH in subsequent experiments.

To determine whether LMWH acts at IB4 ${ }^{+}$and/or IB4 ${ }^{-}$nociceptors to induce mechanical hyperalgesia, we pretreated rats with IB4-saporin, a neurotoxin that selectively depletes IB4 ${ }^{+}$ nonpeptidergic fibers (Vulchanova et al., 2001; Nishiguchi et al., 2004) or SSP-saporin, which depletes IB4 ${ }^{-}$peptidergic fibers (Khasabov et al., 2002; Vierck et al., 2003; Wiley et al., 2007; Choi et al., 2012; Weisshaar and Winkelstein, 2014). These toxins were injected intrathecally, $14 \mathrm{~d}$ before the intradermal injection of
LMWH $(1 \mu \mathrm{g})$ on the dorsum of the hindpaw. A third group of rats was treated with both toxins. In rats treated with either IB4saporin or SSP-saporin, LMWH-induced hyperalgesia was significantly attenuated [IB4-saporin group, by $44.5 \%\left(t_{(22)}=\right.$ $4.162, p=0.0002)$; SSP-saporin group, by $48 \%\left(t_{(22)}=5.341, p<\right.$ $0.0001)]$, and was almost completely abolished in rats treated with both neurotoxins [attenuation by $85.7 \%\left(t_{(22)}=7.762, p<\right.$ $0.0001)$, compared with the control group; unpaired Student's $t$ test (Fig. 2A)], indicating that LMWH acts on both classes of nociceptors to induce mechanical hyperalgesia. To determine whether the total absence of the hyperalgesia induced by LMWH was due to depletion of nociceptors, 1 week later, when the mechanical nociceptive threshold had returned to baseline (data not shown), we injected 8-bromo cAMP or $\psi \varepsilon$ RACK, activators of $\mathrm{PKA}$ and $\mathrm{PKC} \varepsilon$, respectively, both previously shown to play a role as second messengers in nociceptor sensitization and primary mechanical hyperalgesia (Taiwo and Levine, 1991; Aley and Levine, 1999; Aley et al., 2000). Both 8-bromo cAMP and $\psi \varepsilon$ RACK induced hyperalgesia in rats pretreated with IB4-saporin plus SSP-saporin (a reduction of $\sim 20 \%$ in the mechanical nociceptive threshold for both groups, compared with baseline threshold), although it was attenuated compared with the control groups, in which the reduction in the mechanical nociceptive threshold was 35\% (8-bromo cAMPtreated groups: $t_{(10)}=3.907, p=0.0015 ; \psi \varepsilon$ RACK-treated groups: $t_{(10)}=3.501, p=0.0029$, when control and toxin-treated groups are compared; unpaired Student's $t$ test), indicating that the hyperalgesic effect of LMWH is accounted for by its action at IB4 ${ }^{+}$ and IB4 ${ }^{-}$nociceptors, and suggesting the presence of a residual class of nociceptors, unresponsive to $\mathrm{LMWH}$, in which PKA and $\mathrm{PKC} \varepsilon$ can induce sensitization (Fig. $2 B$ ). In addition, because the combination of neurotoxins did not significantly affect nociceptive threshold $\left(t_{(11)}=0.6005, p=0.2802\right.$, nonsignificant, when the mechanical nociceptive threshold is compared before and $14 \mathrm{~d}$ after the treatment with the combination of toxins), these residual nociceptors are also able to contribute to the detection of noxious mechanical stimuli.

\section{LMWH acts at CD44 to induce hyperalgesia}

To confirm that CD44 is the nociceptor receptor at which LMWH and A6, a CD44 agonist, act to induce mechanical hyperalgesia, rats were treated intrathecally with ODN antisense to CD44 mRNA. The effect of ODN (40,80, or $120 \mu \mathrm{g}$, injected daily for 3 consecutive days) was evaluated. On the fourth day, LMWH or A6 (both $1 \mu \mathrm{g}$ ) was injected intradermally on the dorsum of the hindpaw, and the mechanical nociceptive threshold evaluated 30 min later. A dose-dependent attenuation of the hyperalgesia induced by LMWH [40 $\mu \mathrm{g}, 29 \%\left(t_{(10)}=3.981, p=0.0013\right) ; 80 \mu \mathrm{g}, 46.2 \%$ $\left(t_{(10)}=4.337, p=0.0007\right)$, and $120 \mu \mathrm{g}, 92.2 \%\left(t_{(10)}=6.366, p<\right.$ $0.0001)$ ] and A6 [40 $\mu \mathrm{g}, 28.5 \%\left(t_{(10)}=3.041, p=0.0062\right) ; 80 \mu \mathrm{g}$, $58.2 \%\left(t_{(10)}=4.600, p=0.0005\right)$, and $120 \mu \mathrm{g}, 82.5 \%\left(t_{(10)}=\right.$ $5.205, p=0.0002)$, when sense- and antisense-treated groups are compared, unpaired Student's $t$ test] was observed in groups treated with antisense (Fig. 3). As the strongest inhibition of LMWH and A6 hyperalgesia was observed in the groups treated with $120 \mu \mathrm{g} / \mathrm{d}$ of antisense, this dose was used in the remaining experiments.

\section{HMWH-induced antihyperalgesia}

We have previously shown that HMWH attenuates mechanical hyperalgesia induced by LMWH or carrageenan-induced inflammation (Ferrari et al., 2016a). To determine whether treatment with $\mathrm{HMWH}$, in addition to preventing the development of hyperalgesia, also reverses ongoing hyperalgesia, in which intra- 
cellular second messengers are already activated, HMWH was injected after LMWH (Fig. 4A) or pronociceptive inflammatory mediators, which act at their cognate receptors on nociceptors to induce mechanical hyperalgesia, $\mathrm{PGE}_{2}$, epinephrine, TNF $\alpha$, and IL-6 (Fig. 4B). HMWH significantly reversed the hyperalgesia induced by each mediator [LMWH, by $82.8 \%\left(t_{(16)}=\right.$ 5.103, $p<0.0001) ; \mathrm{PGE}_{2}, 66.2 \%\left(t_{(10)}=\right.$ 5.676, $p=0.0001)$; epinephrine, $65.4 \%$ $\left(t_{(10)}=4.150, p=0.0010\right) ; \mathrm{TNF} \alpha$, $51.5 \%\left(t_{(10)}=6.365, p<0.0001\right)$; IL-6, $41.1 \%\left(t_{(10)}=5.461, p=0.0001\right)$, when the controls and HMWH-treated groups are compared 30 min after injection, unpaired Student's $t$ test]. We also tested the effect of HMWH on the hyperalgesia induced by paclitaxel, in a preclinical model of chemotherapy-induced painful neuropathy (Dina et al., 2001; Alvarez et al., 2011) (Fig. 4C). Paclitaxel was injected intraperitoneally ( $1 \mathrm{mg} / \mathrm{kg}$ every other day) 4 times. Twenty-four hours after the last injection, a time point at which robust hyperalgesia was observed $(\sim 33 \%$ reduction in the mechanical nociceptive threshold), vehicle or HMWH was injected intradermally on the dorsum of the hindpaw, at the site of nociceptive testing. HMWH significantly reversed paclitaxel-induced hyperalgesia [by $73.6 \%\left(t_{(10)}=4.677, p=\right.$ 0.0004 , unpaired Student's $t$ test)]. These observations demonstrate a marked antihyperalgesic effect of HMWH in models of inflammatory and neuropathic pain (Fig. 4).

\section{CD44 mediates HMWH-induced antihyperalgesia}

To investigate whether the antihyperalgesia induced by intradermal HMWH is due to its action at CD44, on the peripheral terminal of the nociceptor, we treated rats intrathecally with CD44 antisense for 3 consecutive days and, on the fourth day, TNF $\alpha$ or IL- 6 was injected intradermally on the dorsum of the hindpaw. Thirty minutes later, when the mechanical hyperalgesia induced by these mediators was fully developed (Parada et al., 2003a; Summer et al., 2008; Ferrari et al., 2015b), HMWH was injected at the same site. Mechanical nociceptive threshold was again evaluated $30 \mathrm{~min}$ after HMWH. The hyperalgesia induced by these inflammatory mediators was attenuated only in groups that had been treated with sense ODN [TNF $\alpha$, by $67.0 \%\left(t_{(10)}=7.306, p<0.0001\right)$; IL-6, by $61.4 \%\left(t_{(10)}=9.077, p<0.0001\right)$, when vehicle and HMWH groups are compared, unpaired Student's $t$ test], whereas in the antisense-treated groups, the hy-

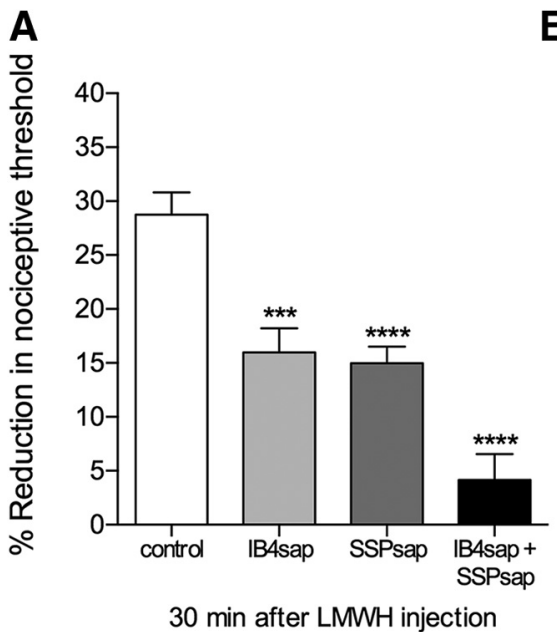

B

Figure 2. Role of peptidergic (IB4 ${ }^{-}$) and nonpeptidergic (IB4 $\left.{ }^{+}\right)$nociceptors in LMWH-induced hyperalgesia. $A$, Separate groups of rats received a single intrathecal injection of one of two neurotoxins, isolectin B4-saporin (IB4sap, selective for nonpeptidergic neurons, $3.2 \mu$ g, light gray bar), or $\left[\mathrm{Sar}{ }^{9}, \mathrm{Met}\left(\mathrm{O}_{2}\right)^{11}\right]$ substance P-saporin (SSPsap, selective for SP-containing fibers, 100 $\mathrm{ng}$, dark gray bar), or their combination (black bar). A control group (white bar) received saline. LMWH (1 $\mu \mathrm{g}$ ) was injected intradermally on the dorsum of the hindpaw $14 \mathrm{~d}$ later. Significant attenuation of LMWH-induced hyperalgesia was observed in all neurotoxin-treated groups (IB4sap: $t_{(22)}=4.162,{ }^{* * *} p=0.0002 ;$ SSPsap: $t_{(22)}=5.341,{ }^{* * * *} p<0.0001$; combination: $t_{(22)}=$ $7.762,{ }^{* * * *} p<0.0001$, compared with the control group; unpaired Student's $t$ test). $B$, One week later, the control group (white bar) and the group treated with the combination of toxins (black bar), shown in $A$, were each further divided into 2 groups, which received an intradermal injection of either 8-bromo cAMP or $\psi \varepsilon R A C K$ (both $1 \mu \mathrm{g}$ ), on the dorsum of the hindpaw. At that time point, the mechanical nociceptive thresholds were not significantly different from pre-LMWH baseline (8-bromo CAMP: control group: $t_{(5)}=0.9715, p=0.1880$; combination group: $t_{(5)}=1.321, p=0.1219 ; \psi \varepsilon$ RACK: control group: $t_{(5)}=1.305, p=$ 0.1244 ; combination group: $t_{(5)}=0.6697, p=0.2664$, all nonsignificant, when the mechanical nociceptive threshold before LMWH injection and immediately before 8-bromo CAMP or $\psi \varepsilon$ RACK injection are compared, paired Student's $t$ test). Robust mechanical hyperalgesia was observed in all groups, 30 min after injection (8-bromo cAMP, control: $t_{(5)}=21.02, p<0.0001$; combination: $t_{(5)}=4.776, p=0.0025 ; \psi \varepsilon R A C K$, control: $t_{(5)}=31.30, p<0.0001$; combination: $t_{(5)}=6.173, p=0.0008$, when the mechanical nociceptive thresholds were compared with baseline thresholds; paired Student's $t$ test), although in the groups pretreated with the combination of the two toxins, there was attenuation compared with the control groups (8-bromo cAMPtreated groups: $t_{(10)}=3.907,{ }^{*} p=0.0015 ; \psi \varepsilon$ RACK-treated groups: $t_{(10)}=3.501,{ }^{* *} p=0.0029$; unpaired Student's $t$ test). $A, n=12$ paws per group. $B, n=6$ paws per group.
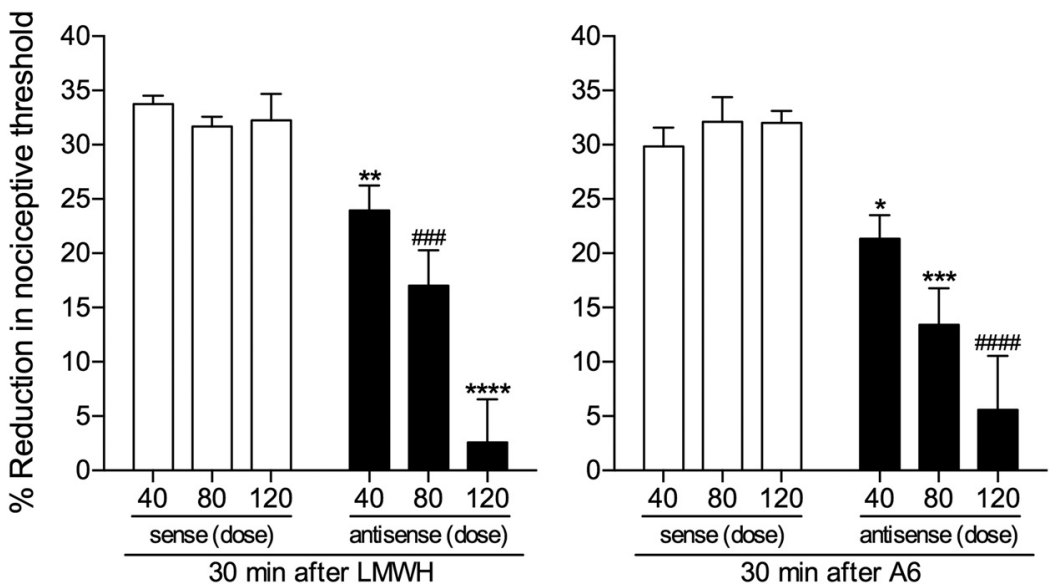

Figure 3. ODN antisense to CD44 mRNA dose-dependently attenuates LMWH- and A6-induced hyperalgesia. Groups of rats were treated daily with 1 of 3 doses (40,80, or $120 \mu \mathrm{g}$, spinal intrathecal injections) of ODN, antisense (black bars) or sense (white bars) for CD44 mRNA, for 3 consecutive days. On the fourth day, LMWH (left) or A6 (right) (both $1 \mu \mathrm{g}$ ) was injected intradermally on the dorsum of the hindpaw and the mechanical nociceptive threshold evaluated 30 min later. LMWH and A6 both induced robust hyperalgesia, with no difference between the groups treated with the different doses of CD44 sense ODN (LMWH-treated groups: $F_{(2,15)}=0.4509, p=0.6454$; A6-treated groups: $F_{(2,15)}=0.5264, p=0.6013$, both nonsignificant, when the hyperalgesia in the three groups is compared, one-way ANOVA followed by Bonferroni post hoc test). However, the hyperalgesia induced by LMWH and A6 was dose-dependently attenuated in the groups pretreated with antisense (LMWH groups, $40 \mu \mathrm{g:} t_{(10)}=3.981$, ${ }^{* *} p=0.0013 ; 80 \mu \mathrm{g}: t_{(10)}=4.337,{ }^{\# \# \#} p=0.0007 ; 120 \mu \mathrm{g}: t_{(10)}=6.366,{ }^{* * * *} p<0.0001 ;$ A6 groups, $40 \mu \mathrm{g}: t_{(10)}=3.041$,

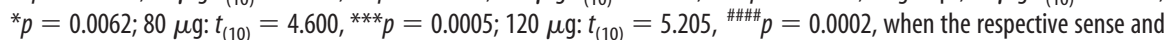
antisense groups are compared; unpaired Student's $t$ test), with the strongest attenuation observed in the group treated with the highest dose $(120 \mu \mathrm{g})$, for both LMWH- and A6-induced hyperalgesia. $n=6$ paws per group. 
A

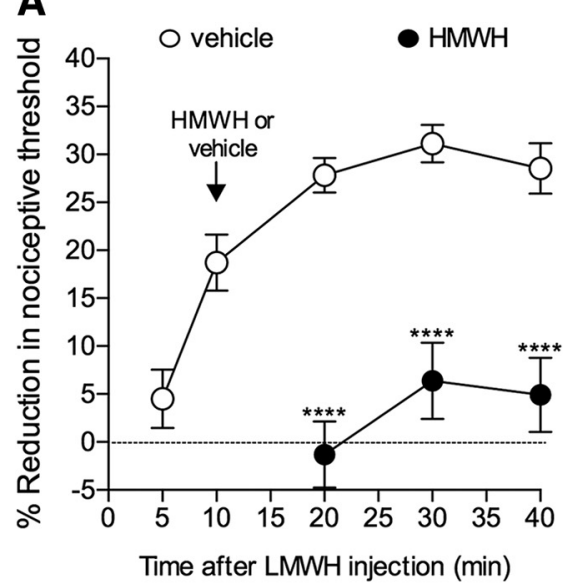

B

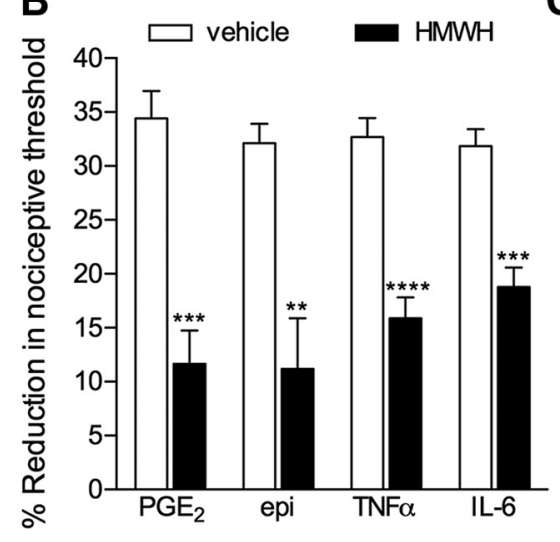

C

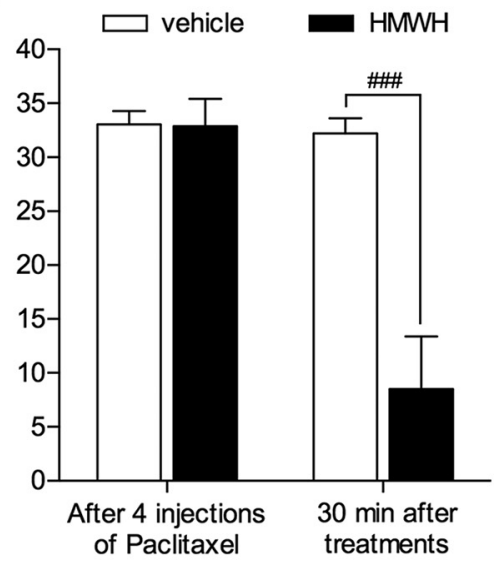

Figure 4. Antihyperalgesic effect of HMWH. $A$, LMWH (1 $\mu \mathrm{g}$ ) was injected intradermally on the dorsum of the hindpaw. Ten minutes later, HMWH (1 $\mu \mathrm{g}$, black circles) or vehicle (open circles) was injected at the same site and the mechanical nociceptive threshold evaluated over time. Significant reversal of LMWH-induced hyperalgesia was observed in the group treated with HMWH $\left(F_{(1.16)}=83.33,{ }^{* * * *} p<0.0001\right.$, when both groups are compared, two-way repeated-measures ANOVA, followed by Bonferroni post hoc test). $\boldsymbol{B}$, Four pronociceptive mediators, PGE 2 (100 ng), epinephrine (epi, $100 \mathrm{ng})$, TNF $\alpha(100 \mathrm{ng})$, or IL-6 (10 ng), were injected intradermally on the dorsum of the hindpaw. Ten minutes after PGE and epinephrine, or 30 min after TNF $\alpha$ and IL-6, HMWH (1 $\mu \mathrm{g}$, black bars) or vehicle (white bars) was injected at the same site. Measurement of the mechanical nociceptive threshold after an additional 30 min showed a significant attenuation of the

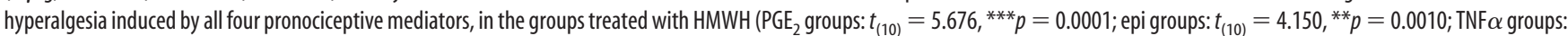
$t_{(10)}=6.365,{ }^{* * * *} p<0.0001 ;$ IL-6 groups: $t_{(10)}=5.461,{ }^{* * *} p=0.0001$, when the vehicle and HMWH groups are compared, unpaired Student's $t$ test). $C$, Rats received four intraperitoneal injections of the neurotoxic chemotherapeutic drug paclitaxel $(1 \mathrm{mg} / \mathrm{kg})$, once every other day. Evaluation of mechanical nociceptive threshold $24 \mathrm{~h}$ after the last injection of paclitaxel showed robust mechanical hyperalgesia. Then HMWH ( $1 \mu \mathrm{g}$, black bar) or vehicle (white bar) was injected intradermally at the site of nociceptive testing on the dorsum of the hindpaw. Mechanical nociceptive threshold was again evaluated $30 \mathrm{~min}$ later. Whereas hyperalgesia was still observed in the vehicle-treated group, in the group that received HMWH, it was markedly attenuated $\left(t_{(10)}=4.677\right.$, $\#=0.0004$, when control and HMWH groups are compared, unpaired Student's $t$ test). $A$, Control group, $n=12$ paws; HMWH group, $n=6 . B, C$, All groups, $n=6$ paws.

A

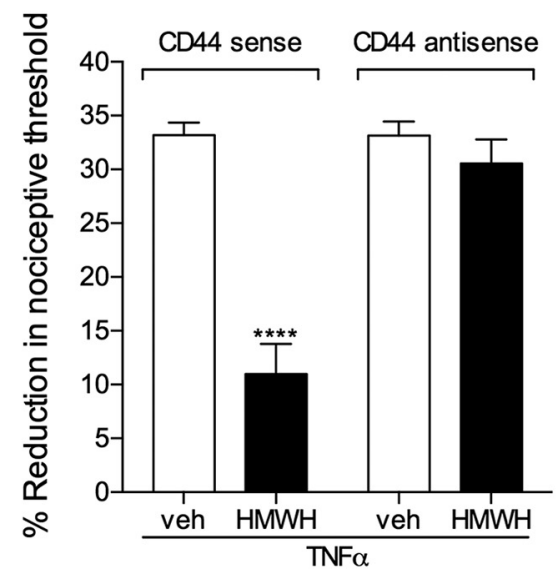

B

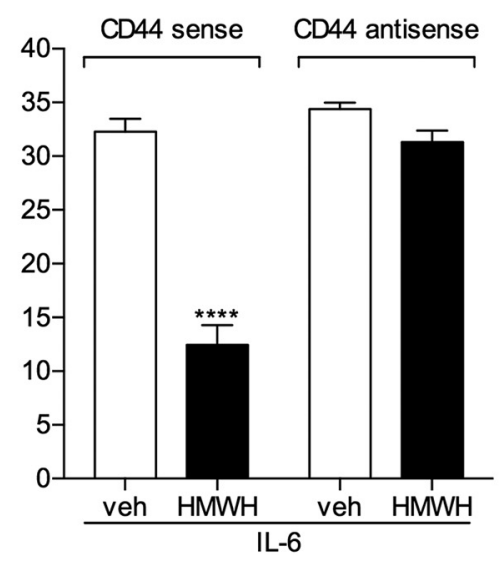

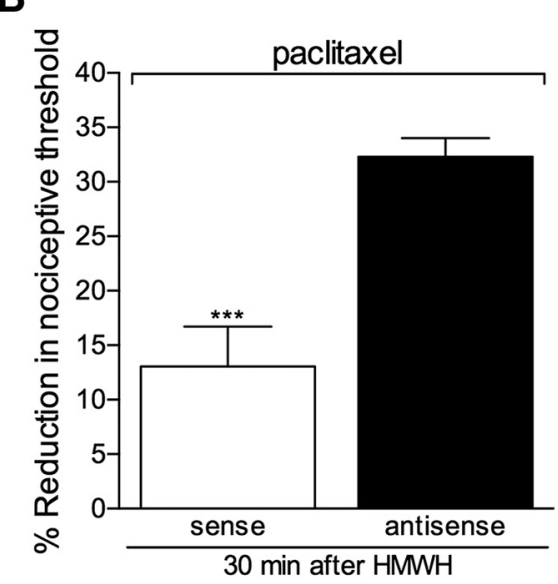

Figure 5. Antihyperalgesic effect of HMWH is CD44-dependent. $A$, Rats were treated daily with a spinal intrathecal injection of 0DN sense or antisense for CD44 mRNA (120 $\mu \mathrm{g}$ ) for 3 consecutive days. On the fourth day, TNF $\alpha$ (100 ng, left) or IL-6 (10 ng, right) was injected intradermally on the dorsum of the hindpaw. Thirty minutes later, vehicle (white bars) or HMWH (1 $\mu \mathrm{g}$, black bars) was injected at the same site. Evaluation of the mechanical nociceptive threshold $30 \mathrm{~min}$ later showed a significant reversal of the hyperalgesia induced by TNF $\alpha$ and IL-6 in the groups that had been treated with antisense, compared with those treated with sense (TNF $\alpha$, sense groups: $t_{(10)}=7.306,{ }^{* * * *} p<0.0001$; antisense groups: $t_{(10)}=1.007, p=0.1688$, nonsignificant; IL-6, sense groups: $t_{(10)}=9.077,{ }^{* * * *} p<0.0001$; antisense groups: $t_{(10)}=0.8891, p=0.1974$, nonsignificant, when the vehicle and HMWH groups are compared, unpaired Student's $t$ test). $\boldsymbol{B}$, Rats received four intraperitoneal injections of the chemotherapeutic drug paclitaxel ( $1 \mathrm{mg} / \mathrm{kg}$, every other day). Intrathecal injections of 0DN sense or antisense were performed, once a day, from days $5-7$ of paclitaxel treatment. At $24 \mathrm{~h}$ after the last injections of paclitaxel and ODNs, vehicle (white bars) or HMWH ( $1 \mu \mathrm{g}$, black bars) was injected intradermally on the dorsum of the hindpaw. Mechanical nociceptive threshold was evaluated before treatment with paclitaxel and 30 min after the injection of vehicle or HMWH. Significant attenuation of paclitaxel-induced hyperalgesia was observed only in the 0DN sense-treated group $\left(t_{(10)}=4.781,{ }^{* * *} p=0.0004\right.$, compared with the antisense-treated group, unpaired Student's $t$ test). Together, these results indicate that HMWH acts at CD44 to produce antihyperalgesia. $n=6$ paws, all groups.

peralgesia was not different from vehicle-treated controls (TNF $\alpha$, $t_{(10)}=1.007, p=0.1688$; IL-6, $t_{(10)}=0.8891, p=0.1974$ ) (Fig. $5 A)$. Similarly, when HMWH was administered to rats with paclitaxel-induced painful neuropathy, pretreated with CD44 sense or antisense for $3 \mathrm{~d}$, the hyperalgesia was attenuated only in the sense-treated group $\left(59.7 \%\right.$ of attenuation, $t_{(10)}=4.781, p=0.0004$, when sense and antisense groups are compared, unpaired Student's $t$ test) (Fig. 5B). These results indicate that the antihyperalgesic effect of HMWH is CD44-mediated.

HMWH attenuates mechanical hyperalgesia induced by second messengers

Because the hyperalgesia induced by LMWH is attenuated by pretreatment with HMWH (Ferrari et al., 2016a), a possible com- 


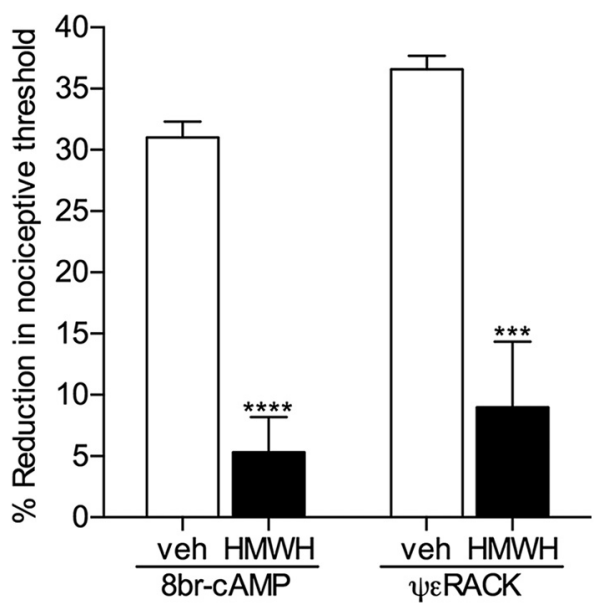

Figure 6. HMWH attenuates mechanical hyperalgesia induced by pronociceptive second messengers. The direct activators of intracellular proalgesic signaling pathways, 8-bromo cAMP (potent PKA activator) or $\psi \varepsilon$ RACK (PKC $\varepsilon$ activator), both $1 \mu \mathrm{g}$, were injected intradermally on the dorsum of the hindpaw; 30 min later, vehicle (white bars) or HMWH (1 $\mu$ g, black bars) was injected at the same site, and the mechanical nociceptive threshold was evaluated an additional 30 min later. Significant attenuation of hyperalgesia induced by both second messengers was observed in the groups treated with HMWH (8-bromo cAMP groups: $t_{(10)}=8.187,{ }^{* * * *} p<$ $0.0001 ; \psi \varepsilon$ RACK groups: $t_{(10)}=5.050,{ }^{* * *} p=0.0002$, when the vehicle and HMWH groups are compared, unpaired Student's $t$ test), indicating that HMWH induces antihyperalgesia by triggering a signaling pathway that decreases nociceptor sensitization. $n=6$ paws per group.

petitive action at CD44 can be suggested. However, HMWH also reversed the ongoing hyperalgesia induced by pronociceptive mediators, such as TNF $\alpha$ and IL-6 (Fig. 4B). Considering that TNF $\alpha$ and IL- 6 do not signal through CD44, as their hyperalgesia was not attenuated by CD44 antisense (Fig. 5A), the antihyperalgesia produced by $\mathrm{HMWH}$ is not the result of a competitive interaction at CD44. To confirm that HMWH attenuates nociceptor sensitization by inhibiting intracellular signaling pathways mediating nociceptor sensitization, we treated rats with 8-bromo cAMP or $\psi \varepsilon$ RACK, activators of PKA and PKC $\varepsilon$, respectively, both second messengers involved in nociceptor sensitization (Aley and Levine, 1999; Aley et al., 2000). At a time at which the magnitude of the mechanical hyperalgesia was significant, $30 \mathrm{~min}$ after injection, HMWH or vehicle was injected at the same site. The hyperalgesia induced by 8 -bromo cAMP and $\psi \varepsilon$ RACK was significantly attenuated in paws that received HMWH (by $82.9 \%$ in the 8-bromo cAMP group, $t_{(10)}=8.187, p<0.0001$; by $75.6 \%$ in the $\psi \varepsilon$ RACK group, $t_{(10)}=5.050, p=0.0002$, when vehicle and HMWH groups are compared, unpaired Student's $t$ test) (Fig. 6), indicating that HMWH produces antihyperalgesia via a second messenger signaling pathway.

\section{HA-induced changes in neuronal excitability in vitro}

Whereas LMWH induces mechanical hyperalgesia (Fig. 1), injection of HMWH produces antihyperalgesia (Fig. 4), attenuating nociceptor sensitization induced by proalgesic mediators. The effects of both LMWH and HMWH are dependent on CD44 expressed on nociceptors, confirmed by the inhibition of their effects by CD44 antisense (Figs. 3, 5). To further confirm the nociceptor as a site of action of LMWH and HMWH, a series of in vitro experiments were conducted in cultured male DRG neurons. Electrophysiological experiments were performed in smalland medium-size neurons (soma diameter $<45 \mu \mathrm{m}$ ), which predominantly represent the $\mathrm{C}$ - and $\mathrm{A} \delta$-type nociceptive subpopulation of primary sensory neurons (Harper and Lawson, 1985; Scroggs and Fox, 1992a, b; Gold et al., 1996). Because we have shown that both peptidergic (IB4 ${ }^{-}$neurons) and nonpeptidergic $\left(\mathrm{IB}^{+}{ }^{+}\right)$neurons are involved in LMWH-induced sensitization (Fig. $2 A$ ), identified IB $4^{+}$and IB4 ${ }^{-}$neurons (Fig. $7 A-C$ ) were included in our experimental groups (approximately halfand-half). Basic parameters of APs generated in response to step current stimulation (current-clamp mode of whole-cell patchclamp) were determined first. We found that administration of LMWH to putative nociceptors (Fig. $7 B$, middle) induced a significant decrease of AP rheobase (minimum current step stimulating AP generation), whereas in control and $\mathrm{HMWH}$ groups (Fig. $7 A$ and $7 C$, respectively, middle panels), there was no significant change from baseline values (Fig. $7 D$, left), suggesting a sensitization effect of LMWH but not HMWH, supporting our in vivo finding. This reduction of rheobase was not due to a hyperpolarizing shift of threshold potential of AP generation, which was not significantly altered in either group (Fig. $7 D$, middle). This implicates other ionic mechanisms as responsible for the initial phase of AP, which has yet to be elucidated. At the same time, the AP induced by step current of the same magnitude revealed no significant difference between $\mathrm{LMWH}, \mathrm{HMWH}$, and control groups in AP overshoot, minimum of AHP and AP amplitude, rise and decay times, and half-width (data not shown). However, parameters of AHP could be significantly affected by ionic conductances activated by the depolarizing step itself, when $\mathrm{AP}$ is recorded during stimulation. In contrast, APs induced by strong but short (1-3 ms) current pulse (and developing after completion of the pulse) should be less affected by stimulation. Use of this stimulation protocol (Fig. $7 A-C$, right panels) uncovered a significantly larger peak AHP in LMWH than in the control and HMWH groups (Fig. 7D, right), suggesting influence of LMWH on repolarization phase of AP and possible effect on firing properties of nociceptors. Other analyzed parameters, including AP overshoot, duration at base, and AHP decay time, were not significantly different between groups and from their baselines. Finally, despite known differences between peptidergic and nonpeptidergic nociceptors in their electrophysiological properties (Snider and McMahon, 1998; Stucky and Lewin, 1999), we did not observe statistically significant differences between these neuronal classes in effect of LMWH on abovementioned parameters, when IB4 ${ }^{+}$and IB4 ${ }^{-}$neurons were analyzed separately (data not shown). In summary, our in vitro electrophysiological studies provide evidence that LMWH and HMWH act on nociceptors differently. LMWH, in contrast to HMWH, directly sensitized nociceptors of both peptidergic and nonpeptidergic classes by reducing magnitude of stimulus required for AP generation, thus confirming our findings from behavioral experiments.

\section{HMWH attenuates $\mathrm{PGE}_{2}$-induced sensitization of cultured DRG neurons}

We have recently shown that HMWH does not significantly influence mechanical nociceptive threshold by itself, in vivo (Ferrari et al., 2016a). Our current study demonstrates remarkable antihyperalgesic properties of HMWH (Fig. 4), suggesting a direct inhibitory effect of $\mathrm{HMWH}$ on nociceptor sensitization induced by pronociceptive mediators. To provide further support for this hypothesis, in vitro experiments were conducted to evaluate the effect of HMWH on the sensitization of cultured DRG neurons by $\mathrm{PGE}_{2}$, tested in our behavioral experiments (Fig. $4 B$ ). In vitro, $\mathrm{PGE}_{2}$ induces sensitization in a fast (within minutes) and reversible manner when acutely administered to cultured DRG neurons, which can be assessed in particular by reduction of rheobase and reduction of latency of AP generation in currentclamp mode of "whole-cell" patch clamp (Gold et al., 1996). The 
A- CONTROL
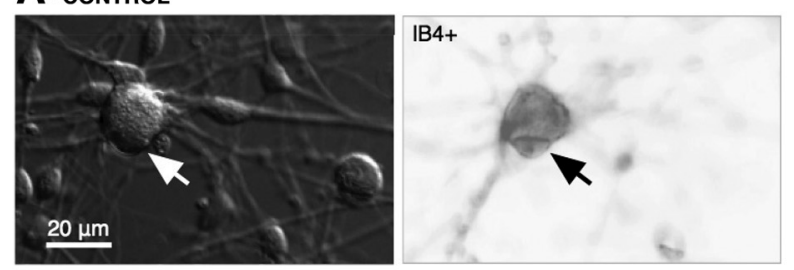

\section{B- Lмwн}
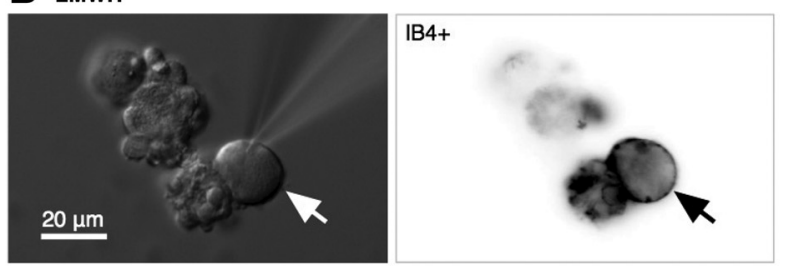

\section{C. нмшн}

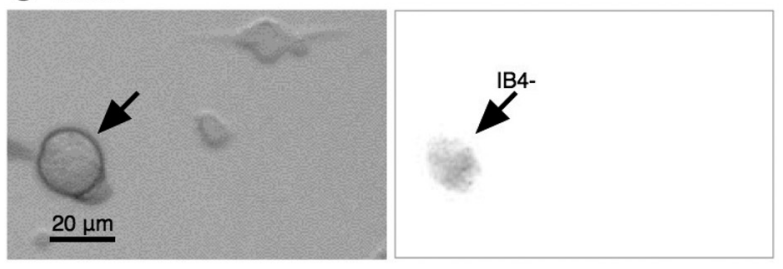

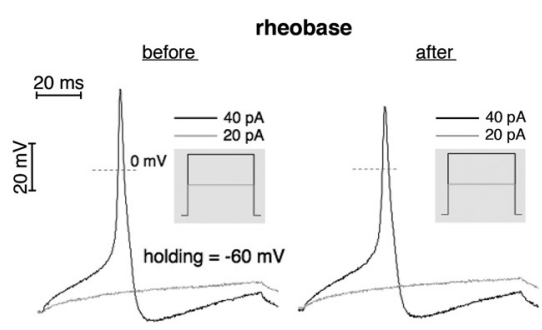
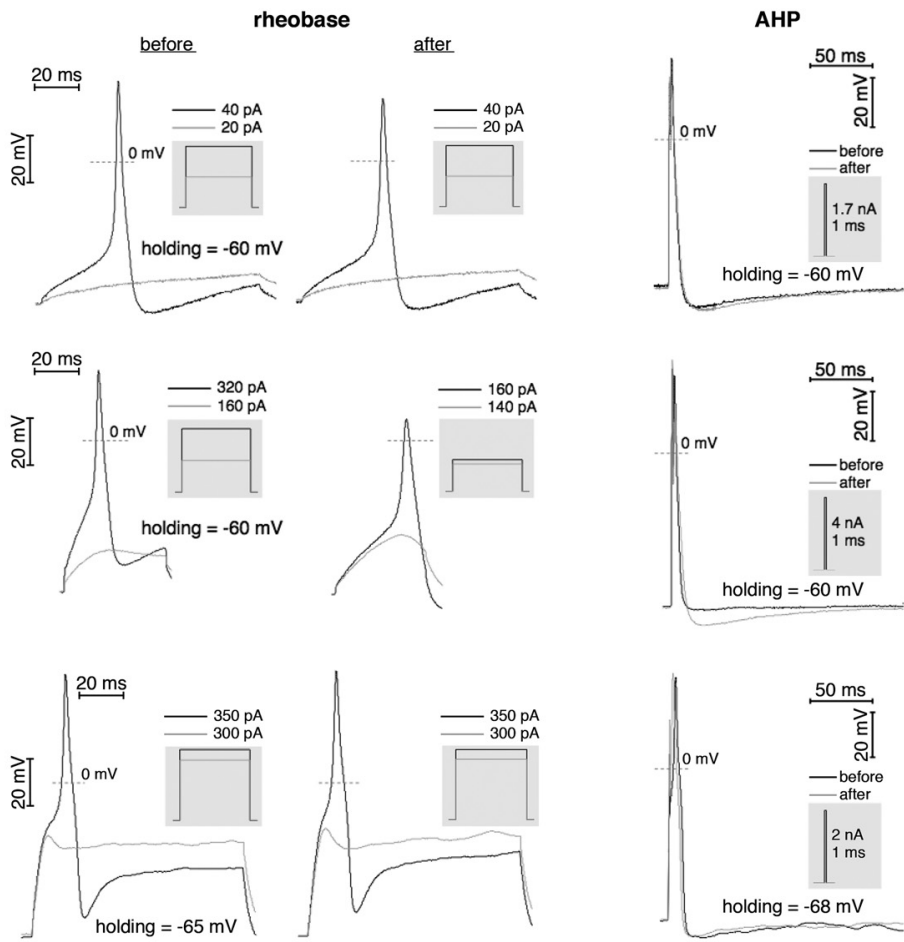

D
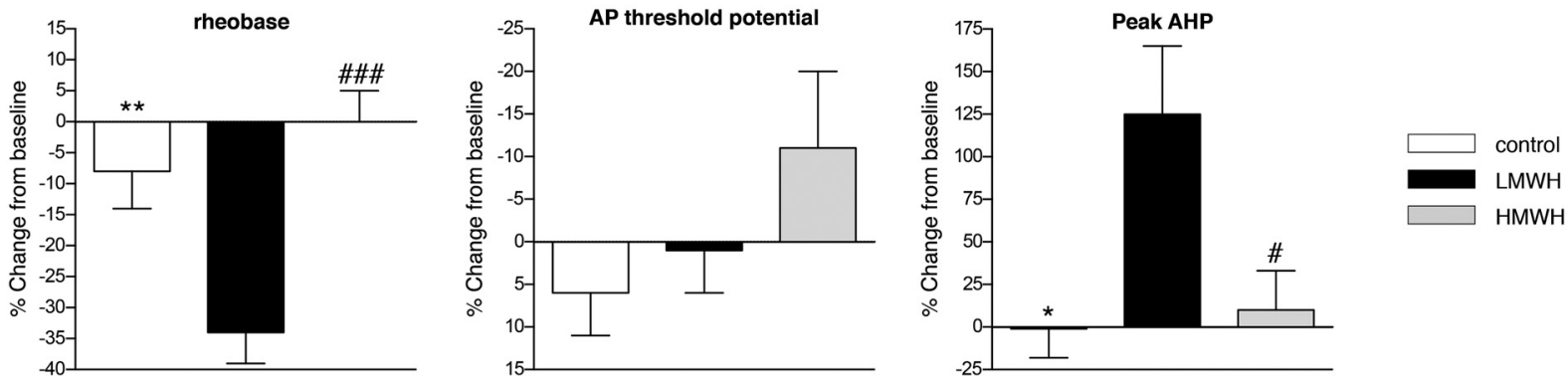

Figure 7. In vitro LMWH, but not HMWH, increases DRG neuron excitability. $A$, Control group. $B$, LMWH group. C, HMWH group. Left columns: Images of neurons, obtained by transmitted light (differential interference contrast, left images) or fluorescence microscopy (right images, in which the darker regions correspond to more intense IB4 binding). $A, B$, IB4 ${ }^{+}$neurons stained with IB4 conjugated with AlexaFluor-488 dye. C, The lack of staining determines the IB4 ${ }^{-}$neuron. Arrows indicate the neurons from which the electrophysiological recordings of APs (middle and right columns) were obtained. $\boldsymbol{A}-\boldsymbol{C}$, Middle columns: The two sets of traces represent AP generation before (left) and after (right) intervention. Black traces represent AP generation in response to rheobase current injection. Gray traces represent the responses to stimulation below rheobase (no AP generation). The magnitude of current pulses is indicated above the inset boxes (gray). Right column: Traces represent the AHP development and recovery after AP induced by $1 \mathrm{~ms}$ current pulse before (black traces) and after (gray traces) intervention. Gray boxes represent stimulation profile in current-clamp mode. D, Pooled relative changes of AP parameters after application of perfusion solution alone (white bars), LMWH (black bars), or HMWH (gray bars). Rheobase (left) was significantly decreased in the LMWH group compared with the control and HMWH groups $\left(F_{(2,28)}=11, p=0.0003\right.$, one-way ANOVA, followed by Bonferroni post hoc test; $t_{(22)}=3.5$, ${ }^{* *} p<0.01$, when LMWH and control groups are compared, $t_{(20)}=4.2,{ }^{\# \# \#} p<0.001$, when LMWH and HMWH groups are compared). In addition, there were no significant differences from baseline in the control and HMWH groups (control group: $t_{(8)}=1.3, p=0.2$; HMWH group: $t_{(6)}=0.0, p=1.0$, compared with 0 by one-sample Student's $t$ test). This suggests that LMWH increases neuronal excitability by reducing rheobase, whereas HMWH does not alter rheobase. Rheobase baseline was $650 \pm 130 \mathrm{pA}(n=32)$. AP threshold potential (middle) was not significantly different between control, LMWH, and HMWH groups, as well as from baseline in each group $\left(F_{(2,26)}=1.5, p=0.25\right.$, one-way ANOVA; $t_{(6)}=1.2, p=0.3$, for the control group; $t_{(14)}=0.2, p=0.8$, for the LMWH group; $t_{(6)}=1.2, p=0.3$, for the HMWH group, compared with 0 by one-sample Student's $t$ test), suggesting that neither LMWH nor HMWH alters AP threshold potential significantly, and the reduction of rheobase is not due to a shift of AP threshold potential. AP threshold potential baseline was $-32 \pm 3 \mathrm{mV}(n=29)$. Of note, as this value is negative, relative decrease makes it "more positive" (i.e., increases threshold, implying less excitability), and vice versa. Therefore, the vertical axis is intentionally inverted to avoid confusion. Although not significant, there is a tendency to a positive shift of AP threshold potential in HMWH group. Peak AHP (right) was significantly increased in the LMWH group, compared with the control and HMWH groups $\left(F_{(2,16)}=5.0, p=0.02\right.$, one-way ANOVA, followed by Dunnett's post hoc test: $q=2.5,{ }^{*} p<0.05$, when LMWH and control groups are compared; $q=2.8,{ }^{\sharp} p<0.05$, when LMWH and HMWH groups are compared). In addition, there were no significant differences from baseline in the control and HMWH groups (control group: $t_{(3)}=0.06, p=0.96$; HMWH group: $t_{(7)}=0.4, p=0.7$, compared with 0 by one-sample Student's $t$ test). This indicates that LMWH, but not HMWH, influences the repolarization phase of the AP, which can impact the generation of following APs. AHP baseline was $5.4 \pm$ $0.5 \mathrm{mV}(n=19)$. In all experiments, readings were obtained $10 \mathrm{~min}$ after the application of perfusion solution alone ( $\boldsymbol{A}$, control; $\boldsymbol{D}$, white bars), LMWH ( $\boldsymbol{B}$, and black bars in $\boldsymbol{D})$ or HMWH ( $\boldsymbol{C}$, and gray bars in $\boldsymbol{D})$ had started, when a stable effect was achieved. To avoid effects of washout, the concentration of LMWH and HMWH $(0.2 \mathrm{mg} / \mathrm{ml})$ was kept constant during recording. Of note, both IB4 ${ }^{+}$ and IB4 ${ }^{-}$neurons were evaluated. There was no significant difference between them in the effects of LMWH or HMWH on either parameter (data not shown). $D$, Left, Control group, $n=9$ neurons; LMWH group, $n=15$ neurons; HMWH group, $n=7$ neurons. Middle, Control group, $n=7$ neurons; LMWH group, $n=15$ neurons; HMWH group, $n=7$ neurons. Right, Control group, $n=4$ neurons; LMWH group, $n=7$ neurons; HMWH group, $n=8$ neurons. 
prevention protocol (preincubation with or without $\mathrm{HMWH}$, readings $10 \mathrm{~min}$ after $\mathrm{PGE}_{2}$ application)

A

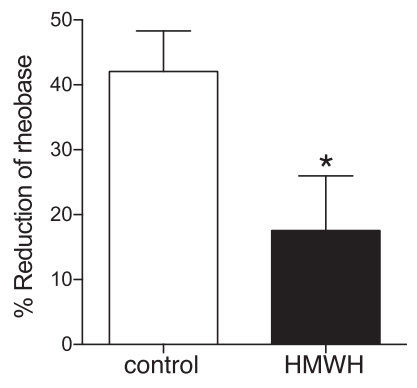

B

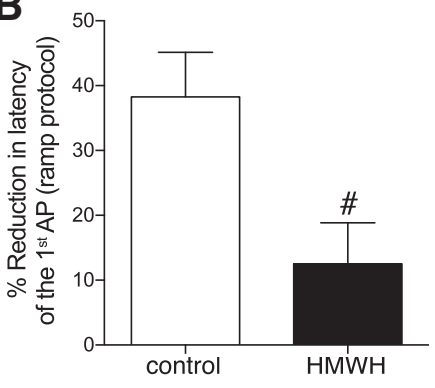

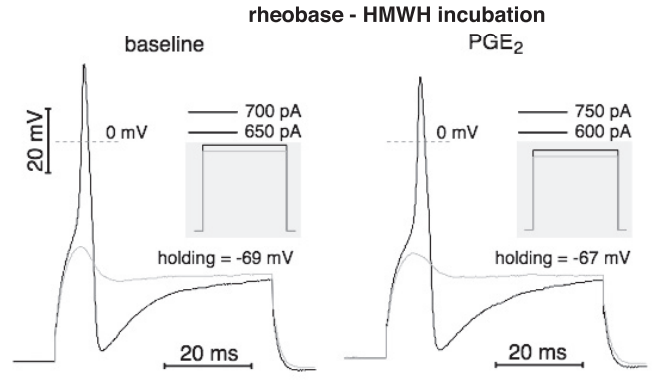

ramp - HMWH incubation

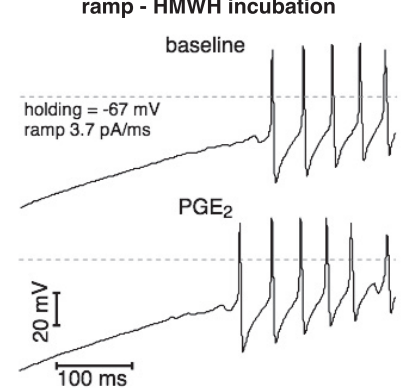

reversal protocol (readings 10 min after application of $\mathrm{HMWH}$, or control, to cultures sensitized by $\mathrm{PGE}_{2}$ application)

C

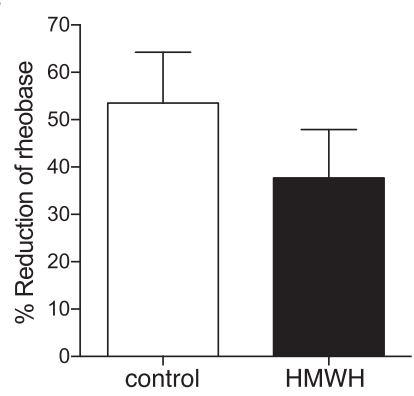

D

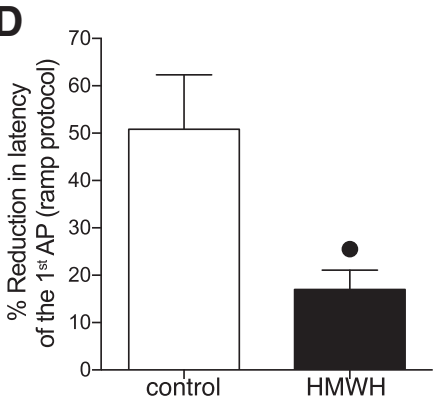

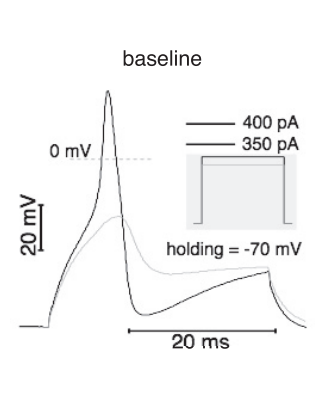

rheobase

$\mathrm{PGE}_{2}$

$\mathrm{HMWH}+\mathrm{PGE}_{2}$
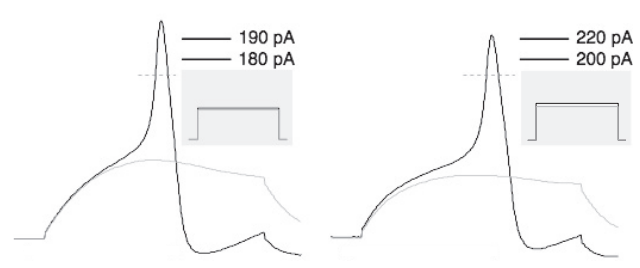

ramp

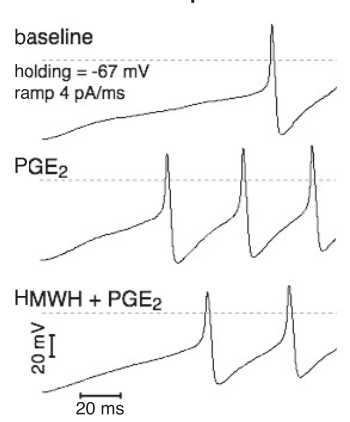

Figure 8. In vitro prevention and reversal of $\mathrm{PGE}_{2}$-induced nociceptor sensitization by HMWH. Neuron sensitization was assessed as relative reduction of rheobase $(\boldsymbol{A}, \boldsymbol{C})$ and latency of the first $A P$ in ramp protocol $(B, D)$, electrophysiological parameters characterizing electrical excitability of neurons. The effect of $H_{M W H}$ on $P G E_{2}$-induced neuron sensitization was examined in prevention and reversal protocols. In prevention protocol $(\boldsymbol{A}, \boldsymbol{B})$, the pronociceptive mediator $\mathrm{PGE}_{2}(1 \mu \mathrm{m})$ was applied (and remained further in the bathing solution) after 30 min preincubation in the presence (black bars) or absence (white bars) of HMWH $(0.2 \mathrm{mg} / \mathrm{ml})$. In the HMWH groups, to avoid effects of washout, the HMWH concentration was kept constant in all solutions during recording, including during $\mathrm{PGE}_{2}$ application. Readings were obtained 10 min after the application of $\mathrm{PGE}_{2}$ had started, when a stable effect was achieved. As observed in the bar graphs (left side of each panel, showing the relative changes of parameters), $\mathrm{PGE}_{2}$ induced significantly smaller reduction of both rheobase $(\boldsymbol{A})$ and latency $(\boldsymbol{B})$ after preincubation with $\mathrm{HMWH}$ compared with the control groups (white bars), indicating the inhibitory effect of preincubation with $\mathrm{HMWH}$ on neuron sensitization induced by $\mathrm{PGE}_{2}\left(\boldsymbol{A}, t_{(13)}=2.3,{ }^{*} p=0.036 ; \boldsymbol{B}, t_{(15)}=2.8,{ }^{*} p=0.015 ;\right.$ when control and $\mathrm{HMWH} \mathrm{groups}$ are compared; unpaired Student's t test with Welch's correction). In reversal protocol (C, D), $\mathrm{PGE}_{2}$ was applied first (and remained further during bathing and applications). When a stable effect was

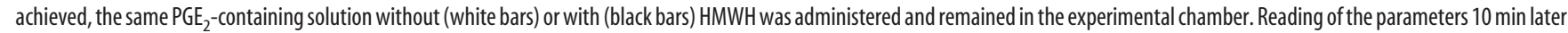
revealed a tendency to attenuation of rheobase reduction $\left(\boldsymbol{C}, t_{(10)}=1.1, p=0.31\right.$, not significant) and significantly smaller reduction of AP latency $\left(\boldsymbol{D}, t_{(7)}=2.8, \boldsymbol{\bullet}_{p}=0.027\right.$, unpaired Student's $t$ test with Welch's correction) when HMWH was administered (black bars), compared with the control (white bars), suggesting at least partial reversal of PGE ${ }_{2}$-induced neuron sensitization by HMWH. Right side of each panel: Respective original trRight side of each panelaces of membrane potential, recorded in current-clamp mode of whole-cell patch clamp, illustrating the onset of APs. Vertical calibration for all traces: $20 \mathrm{mV}$. Horizontal calibration: $20 \mathrm{~ms}$ for all traces, except for $\boldsymbol{B}(100 \mathrm{~ms})$. $\boldsymbol{A}, \boldsymbol{C}$, Black traces represent AP generation in response to rheobase current injection. Gray traces represent responses to stimulation below rheobase (no AP generation). The magnitude of the current pulses is shown above the boxes illustrating the stimulation profile (gray insets). $\boldsymbol{B}, \boldsymbol{D}, \mathbf{G}$ Generation of APs in response to ramp current injection. The traces corresponding to the different treatments ( $\mathrm{PGE}_{2}$ or $\mathrm{PGE}_{2}+\mathrm{HMWH}$ ) are stacked vertically to emphasize changes in latency (Figure legend continues.) 
effect of $\mathrm{HMWH}$ on $\mathrm{PGE}_{2}$-induced sensitization was tested by this approach using prevention and reversal protocols in cultured small-diameter DRG neurons. Of note, both IB $4^{+}$and IB4 ${ }^{-}$neurons were evaluated (Fig. 8). In agreement with the literature, $\mathrm{PGE}_{2}$ alone (control groups) induced reduction of both rheobase and AP latency by $\sim 40 \%-50 \%$ from baseline. In a prevention protocol, in which $\mathrm{PGE}_{2}$ was administered after preincubation with $\mathrm{HMWH}, \mathrm{PGE}_{2}$-induced reduction of rheobase and AP latency were significantly attenuated compared with controls $\left(t_{(13)}=2.3\right.$, $p=0.036$ and $t_{(15)}=2.8, p=0.015$, respectively, when control and HMWH groups are compared; unpaired Student's $t$ test with Welch correction) (Fig. 8A,B). In the reversal protocol, in which HMWH was administered after $\mathrm{PGE}_{2}$-induced neuron sensitization, only attenuation of AP latency reached statistical significance $\left(t_{(7)}=2.8, p=0.027\right)$, with tendency to attenuation of rheobase (Fig. 8C,D). However, the difference between reduction of rheobase and reduction of AP latency in HMWH group in the reversal protocol was not significant $\left(t_{(10)}=1.1, p=0.31\right)$, not allowing us to rule out whether mechanisms of AP generation during step and ramp stimulations were affected differently. Thus, in vitro HWMH can effectively prevent the induction of sensitization as well as reverse ongoing sensitization, similar to what we have observed in vivo.

\section{Discussion}

The study of mechanisms involved in the contribution of ECM to pain following inflammation, still a relatively young field, has identified molecules responsible for the impact of ECM on nociceptor function (Hucho and Levine, 2007; Li et al., 2012; Chen et al., 2014; Bogen et al., 2015; Tajerian and Clark, 2015). Similar to processes such as wound healing and cell growth and migration, which are triggered by the focal increase in levels of HA fragments as a consequence of its metabolism by hyaluronidases (Csóka et al., 1997; Buhren et al., 2016), the release of LMWH from the ECM by tissue injury has been suggested to directly change the sensitivity of nociceptors to mechanical stimulation, through a mechanism involving the cell surface receptor CD44 (Ferrari et al., 2016a). Here, we present evidence that CD44 is the receptor at which HA acts to modulate nociceptor sensitization.

We previously demonstrated that the intradermal injection of hyaluronidase or LMWH induces mechanical hyperalgesia, suggesting that this enzyme, which is activated by the inflammatory process, metabolizing $\mathrm{HMWH}$ to $\mathrm{LMWH}$, contributes to acute inflammatory hyperalgesia (Ferrari et al., 2016a). A6, a CD44 agonist, also produced hyperalgesia, which was attenuated by A5G27, a peptide that binds to CD44 and inhibits its activation (Hibino et al., 2004; Pesarrodona et al., 2014). As A5G27 also attenuated the hyperalgesia produced by LMWH, we proposed CD44 as the receptor at which LMWH acts to produce nociceptor sensitization, supported by the current experiments showing inhibition of LMWH-induced hyperalgesia by the knockdown of nociceptor CD44 with intrathecal administration of ODN antisense to CD44 mRNA (Fig. 3). Hence, the activation of CD44 in

\footnotetext{
$\leftarrow$

(Figure legend continued.) of the first AP. A, B, Right: Traces recorded in the same neuron after preincubation with $\mathrm{HMWH}$, before and after $\mathrm{PGE}_{2}$ application (note the larger changes induced by $\mathrm{PGE}_{2}$ without $\mathrm{HMWH}$ shown in middle traces from $\left.\boldsymbol{C}, \boldsymbol{D}\right)$. $\boldsymbol{C}$, Left, Middle, and Right sets of traces, $\boldsymbol{D}$, Top, Middle, and Bottom traces: Recordings before interventions, after $\mathrm{PGE}_{2}$ and HMWH applications, correspondingly. $A$, Control group, $n=17$ neurons; HMWH group, $n=7$ neurons. $\boldsymbol{B}$, Control group, $n=15$ neurons; HMWH group, $n=6$ neurons. $C$, Control group, $n=6$ neurons; HMWH group, $n=7$ neurons. $\boldsymbol{D}$, Control group, $n=7$ neurons; HMWH group, $n=6$ neurons.
}

the peripheral terminal of the nociceptor, by low molecular weight forms of HA, contributes to the decrease in mechanical nociceptive threshold observed during inflammation.

Previous reports have associated the different cellular effects of HA to its molecular weight (Stern et al., 2006; Aya and Stern, 2014). In addition, the ability of HA to bind CD44 and induce specific cell responses was also shown to be affected by its molecular weight (Underhill, 1992; Tammi et al., 1998; Lesley et al., 2000; Louderbough and Schroeder, 2011; Padmanabhan and Gonzalez, 2012; Senbanjo and Chellaiah, 2017). For example, whereas lower molecular weight HA positively regulates inflammation by stimulating the release of proinflammatory cytokines, increasing chemokine expression (McKee et al., 1996; Yamawaki et al., 2009; Campo et al., 2010) and potentiating the immune response (Ruppert et al., 2014; Vistejnova et al., 2014), via interaction with CD44, higher molecular weight HA has anti-inflammatory and immunosuppressant effects (Cuff et al., 2001; Mizrahy et al., 2011; Kataoka et al., 2013; Ruppert et al., 2014; Furuta et al., 2017; Wu et al., 2017).

In line with these reports showing opposing effects on cell function depending on HA molecular weight, we observed that $\mathrm{HMWH}$, which, in contrast to LMWH, did not by itself affect mechanical nociceptive threshold, prevented nociceptor sensitization and mechanical hyperalgesia. Pretreatment with $\mathrm{HMWH}$ prevented the induction of mechanical hyperalgesia by LMWH and carrageenan (Ferrari et al., 2016a), demonstrating that the size of HA (in this study, LMWH molecular weight $=1200$, and $\mathrm{HMWH}=5 \times 10^{5}$ to $1.2 \times 10^{6}$ ) differentially impacts the effect of HA on nociceptor function, as observed in other cell types (Stern et al., 2006; Aya and Stern, 2014). Moreover, because both high and low molecular weight forms of HA have been shown to bind to CD44 (Lesley et al., 2000; Aya and Stern, 2014; OrianRousseau and Sleeman, 2014), we determined whether the inhibitory effect of $\mathrm{HMWH}$ on the hyperalgesia induced by hyaluronidase and LMWH (Ferrari et al., 2016a) was due to a competitive interaction at CD44. Instead, we found that HMWH could reverse ongoing hyperalgesia induced by LMWH. That HMWH initiates signaling in nociceptors to induce antihyperalgesia is supported by our finding of reversal of ongoing hyperalgesia induced by multiple proalgesic inflammatory mediators, $\mathrm{PGE}_{2}$, epinephrine, TNF $\alpha$, and IL- 6 , as well as the neuropathic hyperalgesia induced by the chemotherapeutic drug paclitaxel (Fig. 4). Also, additional evidence that HMWH induces antihyperalgesia through second messenger signaling is provided by our results showing attenuation of the hyperalgesia associated with activation of PKA and $\mathrm{PKC} \varepsilon$, second messengers involved in nociceptor sensitization (Aley and Levine, 1999; Aley et al., 2000), by HMWH. Together, these observations indicate that the antihyperalgesic effect of HMWH results from a signaling pathway downstream of CD44, which reverses nociceptor sensitization.

That LMWH-induced hyperalgesia was attenuated in rats pretreated with either IB4-saporin $(44.5 \%)$ or SSP-saporin (48\%) supports the suggestion that LMWH sensitizes both peptidergic and nonpeptidergic nociceptors. While the combined depletion of $\mathrm{IB}^{+}{ }^{+}$and IB4 ${ }^{-}$nociceptors totally eliminated LMWH-induced hyperalgesia, unexpectedly, mechanical nociceptive threshold was not significantly increased and activators of PKA and PKC $\varepsilon$, 8-bromo cAMP or $\psi \varepsilon$ RACK, respectively, still produced robust mechanical hyperalgesia (Fig. 2), compatible with the presence of a novel class of nociceptors that is not sensitized by LMWH.

The hyperalgesia induced by LMWH and the CD44 agonist A6 involves PKA and Src as second messengers (Ferrari et al., 2016a). In a recent study, change in intracellular calcium levels in sensory 
neurons, increasing their excitability, was observed after activation of CD44 and a subsequent second messenger cascade that involved Src family kinases and focal adhesion kinase (Ghosh et al., 2011). Modulation of intracellular calcium by CD44 signaling to the endoplasmic reticulum, which could impact cell excitability, has also been reported (Singleton and Bourguignon, 2002, 2004). On the other hand, in regard to the mechanism downstream of CD44 by which HMWH induces antihyperalgesia, a multitude of signaling pathways activated by HMWH have been described (Forrester and Balazs, 1980; Morrison et al., 2001; Jiang et al., 2005; Stern et al., 2006; Aya and Stern, 2014; Ruppert et al., 2014; Litwiniuk et al., 2016). For instance, during the early stages of tissue fibrosis, HMWH has been shown to regulate the interaction of CD44 with coreceptors, leading to activation of second messengers, such as MAPK/ERK (Meran et al., 2011). Conversely, HMWH also has been reported to act at CD44 to inhibit ERK phosphorylation and downregulate translocation of a transcription factor, $\mathrm{NF} \kappa \mathrm{B}$, decreasing the expression of proinflammatory cytokines and tapering the progression of inflammation (Hashizume and Mihara, 2010; Yasuda, 2011). Future experiments, however, will be required to elucidate the second messengers mediating the antihyperalgesic effect of HMWH observed in our model.

When LMWH was applied to small-diameter DRG neurons in vitro, a significant increase in excitability was observed, confirming a direct pronociceptive effect of LMWH (Ferrari et al., 2016a). HMWH, however, produced a small, not statistically significant, decrease in excitability of cultured neurons, but both prevented and reversed nociceptor sensitization induced by $\mathrm{PGE}_{2}$. Other researchers have also shown inhibitory effects of high molecular weight forms of HA, in non-neuronal cells (Nakamura et al., 2004; Muto et al., 2009; Jiang et al., 2011) and in neurons (Caires et al., 2015). Caires and colleagues demonstrated that HMWH induced negative regulation of transient receptor potential vanilloid subtype 1 channel (TRPV1) activity, decreased bradykinininduced neuron sensitization, and attenuated the nocifensive response to heat, $\mathrm{pH}$, and capsaicin, as a consequence of reduced opening probability of TRPV1, by stabilizing its closed state. Together, these findings indicate that the effect of HMWH on the nociceptor results from a cellular mechanism that decreases its excitability, rather than from its viscoelastic properties, as previously proposed (Radin et al., 1970; Unsworth et al., 1975; Mabuchi et al., 1994; Elmorsy et al., 2014; Cowman et al., 2015).

The current data support the suggestion that HMWH and LMWH act on CD44, expressed in the same cell, producing opposing effects on nociception. Still, our experiments do not resolve whether LMWH and HMWH are acting at the same molecular isoform of this receptor. Several CD44 splice variants have been described (Haynes et al., 1991; Kaaijk et al., 1997; Witt and Kasper, 1998; Orian-Rousseau and Sleeman, 2014; Zaiden et al., 2017), and the ODN antisense sequence used in our experiments could affect expression of more than one isoform through which the effects of LMWH and HMWH are mediated. Considering that LMWH and HMWH do not act competitively at the same receptor, rather each activating its own CD44-dependent signaling pathway, we cannot currently rule out this possibility.

In conclusion, this study advances our knowledge of the role of the ECM in nociceptor function, and confirms CD44 as the nociceptor receptor for the effects of HA. Although our understanding of the mechanisms involved in the effects of HA on nociceptor function are in their infancy, the evidence here shown strongly suggests CD44 as a target for therapeutic interventions to alleviate both inflammatory and neuropathic pain.

\section{References}

Adams JD, Flora KP, Goldspiel BR, Wilson JW, Arbuck SG, Finley R (1993) Taxol: a history of pharmaceutical development and current pharmaceutical concerns. J Natl Cancer Inst Monogr 15:141-147. Medline

Agrawal SM, Lau L, Yong VW (2008) MMPs in the central nervous system: where the good guys go bad. Semin Cell Dev Biol 19:42-51. CrossRef Medline

Aley KO, Levine JD (1999) Role of protein kinase A in the maintenance of inflammatory pain. J Neurosci 19:2181-2186. Medline

Aley KO, Messing RO, Mochly-Rosen D, Levine JD (2000) Chronic hypersensitivity for inflammatory nociceptor sensitization mediated by the epsilon isozyme of protein kinase C. J Neurosci 20:4680-4685. Medline

Altman RD, Moskowitz R (1998) Intraarticular sodium hyaluronate (Hyalgan) in the treatment of patients with osteoarthritis of the knee: a randomized clinical trial. Hyalgan Study Group. J Rheumatol 25:2203-2212. Medline

Alvarez P, Ferrari LF, Levine JD (2011) Muscle pain in models of chemotherapy-induced and alcohol-induced peripheral neuropathy. Ann Neurol 70:101-109. CrossRef Medline

Apfel SC, Lipton RB, Arezzo JC, Kessler JA (1991) Nerve growth factor prevents toxic neuropathy in mice. Ann Neurol 29:87-90. CrossRef Medline

Aya KL, Stern R (2014) Hyaluronan in wound healing: rediscovering a major player. Wound Repair Regen 22:579-593. CrossRef Medline

Bajorath J, Greenfield B, Munro SB, Day AJ, Aruffo A (1998) Identification of CD44 residues important for hyaluronan binding and delineation of the binding site. J Biol Chem 273:338-343. CrossRef Medline

Basakran NS (2015) CD44 as a potential diagnostic tumor marker. Saudi Med J 36:273-279. CrossRef Medline

Bogen O, Alessandri-Haber N, Chu C, Gear RW, Levine JD (2012) Generation of a pain memory in the primary afferent nociceptor triggered by PKC $\varepsilon$ activation of CPEB. J Neurosci 32:2018-2026. CrossRef Medline

Bogen O, Bender O, Löwe J, Blenau W, Thevis B, Schröder W, Margolis RU, Levine JD, Hucho F (2015) Neuronally produced versican V2 renders C-fiber nociceptors IB4-positive. J Neurochem 134:147-155. CrossRef Medline

Borle AB, Snowdowne KW (1982) Measurement of intracellular free calcium in monkey kidney cells with aequorin. Science 217:252-254. CrossRef Medline

Bourguignon LY, Shiina M, Li JJ (2014) Hyaluronan-CD44 interaction promotes oncogenic signaling, microRNA functions, chemoresistance, and radiation resistance in cancer stem cells leading to tumor progression. Adv Cancer Res 123:255-275. CrossRef Medline

Buhren BA, Schrumpf H, Hoff NP, Bölke E, Hilton S, Gerber PA (2016) Hyaluronidase: from clinical applications to molecular and cellular mechanisms. Eur J Med Res 21:5. CrossRef Medline

Burch RM, Axelrod J (1987) Dissociation of bradykinin-induced prostaglandin formation from phosphatidylinositol turnover in Swiss 3T3 fibroblasts: evidence for $\mathrm{G}$ protein regulation of phospholipase A2. Proc Natl Acad Sci U S A 84:6374-6378. CrossRef Medline

Caires R, Luis E, Taberner FJ, Fernandez-Ballester G, Ferrer-Montiel A, Balazs EA, Gomis A, Belmonte C, de la Peña E (2015) Hyaluronan modulates TRPV1 channel opening, reducing peripheral nociceptor activity and pain. Nat Commun 6:8095. CrossRef Medline

Campo GM, Avenoso A, Campo S, D’Ascola A, Nastasi G, Calatroni A (2010) Small hyaluronan oligosaccharides induce inflammation by engaging both toll-like-4 and CD44 receptors in human chondrocytes. Biochem Pharmacol 80:480-490. CrossRef Medline

Campo GM, Avenoso A, D'Ascola A, Scuruchi M, Prestipino V, Nastasi G, Calatroni A, Campo S (2012) The inhibition of hyaluronan degradation reduced pro-inflammatory cytokines in mouse synovial fibroblasts subjected to collagen-induced arthritis. J Cell Biochem 113:1852-1867. CrossRef Medline

Carulli D, Laabs T, Geller HM, Fawcett JW (2005) Chondroitin sulfate proteoglycans in neural development and regeneration. Curr Opin Neurobiol 15:116-120. CrossRef Medline

Cavaletti G, Tredici G, Braga M, Tazzari S (1995) Experimental peripheral neuropathy induced in adult rats by repeated intraperitoneal administration of taxol. Exp Neurol 133:64-72. CrossRef Medline

Cavaletti G, Cavalletti E, Montaguti P, Oggioni N, De Negri O, Tredici G (1997) Effect on the peripheral nervous system of the short-term intravenous administration of paclitaxel in the rat. Neurotoxicology 18:137145. Medline

Chen P, Cescon M, Megighian A, Bonaldo P (2014) Collagen VI regulates 
peripheral nerve myelination and function. FASEB J 28:1145-1156. CrossRef Medline

Choi JI, Koehrn FJ, Sorkin LS (2012) Carrageenan induced phosphorylation of Akt is dependent on neurokinin- 1 expressing neurons in the superficial dorsal horn. Mol Pain 8:4. CrossRef Medline

Cliffer KD, Siuciak JA, Carson SR, Radley HE, Park JS, Lewis DR, Zlotchenko E, Nguyen T, Garcia K, Tonra JR, Stambler N, Cedarbaum JM, Bodine SC, Lindsay RM, DiStefano PS (1998) Physiological characterization of Taxol-induced large-fiber sensory neuropathy in the rat. Ann Neurol 43:46-55. CrossRef Medline

Cohen LB, Keynes RD, Hille B (1968) Light scattering and birefringence changes during nerve activity. Nature 218:438-441. CrossRef Medline

Cohen MM, Altman RD, Hollstrom R, Hollstrom C, Sun C, Gipson B (2008) Safety and efficacy of intra-articular sodium hyaluronate (Hyalgan) in a randomized, double-blind study for osteoarthritis of the ankle. Foot Ankle Int 29:657-663. CrossRef Medline

Cowman MK, Schmidt TA, Raghavan P, Stecco A (2015) Viscoelastic properties of hyaluronan in physiological conditions. F1000Res 4:622. CrossRef Medline

Csóka TB, Frost GI, Stern R, Csóka AB (1997) Hyaluronidases in tissue invasion. Invasion Metastasis 17:297-311. Medline

Cuff CA, Kothapalli D, Azonobi I, Chun S, Zhang Y, Belkin R, Yeh C, Secreto A, Assoian RK, Rader DJ, Puré E (2001) The adhesion receptor CD44 promotes atherosclerosis by mediating inflammatory cell recruitment and vascular cell activation. J Clin Invest 108:1031-1040. CrossRef Medline

Dina OA, Chen X, Reichling D, Levine JD (2001) Role of protein kinase Cepsilon and protein kinase $\mathrm{A}$ in a model of paclitaxel-induced painful peripheral neuropathy in the rat. Neuroscience 108:507-515. CrossRef Medline

Dina OA, Green PG, Levine JD (2008) Role of interleukin-6 in chronic muscle hyperalgesic priming. Neuroscience 152:521-525. CrossRef Medline

Dougados M, Nguyen M, Listrat V, Amor B (1993) High molecular weight sodium hyaluronate (hyalectin) in osteoarthritis of the knee: a 1 year placebo-controlled trial. Osteoarthritis Cartilage 1:97-103. CrossRef Medline

Duzhyy DE, Viatchenko-Karpinski VY, Khomula EV, Voitenko NV, Belan PV (2015) Upregulation of T-type $\mathrm{Ca}^{2+}$ channels in long-term diabetes determines increased excitability of a specific type of capsaicin-insensitive DRG neurons. Mol Pain 11:29. CrossRef Medline

Dzwonek J, Wilczynski GM (2015) CD44: molecular interactions, signaling and functions in the nervous system. Front Cell Neurosci 9:175. CrossRef Medline

Elmorsy S, Funakoshi T, Sasazawa F, Todoh M, Tadano S, Iwasaki N (2014) Chondroprotective effects of high-molecular-weight cross-linked hyaluronic acid in a rabbit knee osteoarthritis model. Osteoarthritis Cartilage 22:121-127. CrossRef Medline

Ferrari LF, Araldi D, Levine JD (2015a) Distinct terminal and cell body mechanisms in the nociceptor mediate hyperalgesic priming. J Neurosci 35:6107-6116. CrossRef Medline

Ferrari LF, Bogen O, Reichling DB, Levine JD (2015b) Accounting for the delay in the transition from acute to chronic pain: axonal and nuclear mechanisms. J Neurosci 35:495-507. CrossRef Medline

Ferrari LF, Araldi D, Bogen O, Levine JD (2016a) Extracellular matrix hyaluronan signals via its CD44 receptor in the increased responsiveness to mechanical stimulation. Neuroscience 324:390-398. CrossRef Medline

Ferrari LF, Khomula EV, Araldi D, Levine JD (2016b) Marked sexual dimorphism in the role of the ryanodine receptor in a model of pain chronification in the rat. Sci Rep 6:31221. CrossRef Medline

Finlayson M (2015) Modulation of CD44 activity by A6-peptide. Front Immunol 6:135. CrossRef Medline

Forrester JV, Balazs EA (1980) Inhibition of phagocytosis by high molecular weight hyaluronate. Immunology 40:435-446. Medline

Furuta J, Ariyoshi W, Okinaga T, Takeuchi J, Mitsugi S, Tominaga K, Nishihara T (2017) High molecular weight hyaluronic acid regulates MMP13 expression in chondrocytes via DUSP10/MKP5. J Orthop Res 35:331339. CrossRef Medline

Gaudet AD, Popovich PG (2014) Extracellular matrix regulation of inflammation in the healthy and injured spinal cord. Exp Neurol 258:24-34. CrossRef Medline

Ghosh B, Li Y, Thayer SA (2011) Inhibition of the plasma membrane $\mathrm{Ca}^{2+}$ pump by CD44 receptor activation of tyrosine kinases increases the action potential afterhyperpolarization in sensory neurons. J Neurosci 31:23612370. CrossRef Medline

Gold MS, Reichling DB, Shuster MJ, Levine JD (1996) Hyperalgesic agents increase a tetrodotoxin-resistant $\mathrm{Na}^{+}$current in nociceptors. Proc Natl Acad Sci U S A 93:1108-1112. CrossRef Medline

Goodison S, Urquidi V, Tarin D (1999) CD44 cell adhesion molecules. Mol Pathol 52:189-196. CrossRef Medline

Gorlewicz A, Wlodarczyk J, Wilczek E, Gawlak M, Cabaj A, Majczynski H, Nestorowicz K, Herbik MA, Grieb P, Slawinska U, Kaczmarek L, Wilczynski GM (2009) CD44 is expressed in non-myelinating Schwann cells of the adult rat, and may play a role in neurodegeneration-induced glial plasticity at the neuromuscular junction. Neurobiol Dis 34:245-258. CrossRef Medline

Hamers FP, Pette C, Neijt JP, Gispen WH (1993) The ACTH-(4-9) analog, ORG 2766, prevents taxol-induced neuropathy in rats. Eur J Pharmacol 233:177-178. CrossRef Medline

Harper AA, Lawson SN (1985) Conduction velocity is related to morphological cell type in rat dorsal root ganglion neurones. J Physiol 359:31-46. CrossRef Medline

Hashizume M, Mihara M (2010) High molecular weight hyaluronic acid inhibits IL-6-induced MMP production from human chondrocytes by up-regulating the ERK inhibitor, MKP-1. Biochem Biophys Res Commun 403:184-189. CrossRef Medline

Haynes BF, Liao HX, Patton KL (1991) The transmembrane hyaluronate receptor (CD44): multiple functions, multiple forms. Cancer Cells 3:347350. Medline

Hendrich J, Alvarez P, Joseph EK, Chen X, Bogen O, Levine JD (2013) Electrophysiological correlates of hyperalgesic priming in vitro and in vivo. Pain 154:2207-2215. CrossRef Medline

Hibino S, Shibuya M, Engbring JA, Mochizuki M, Nomizu M, Kleinman HK (2004) Identification of an active site on the laminin alpha5 chain globular domain that binds to CD44 and inhibits malignancy. Cancer Res 64:4810-4816. CrossRef Medline

Hucho T, Levine JD (2007) Signaling pathways in sensitization: toward a nociceptor cell biology. Neuron 55:365-376. CrossRef Medline

Jiang D, Liang J, Fan J, Yu S, Chen S, Luo Y, Prestwich GD, Mascarenhas MM, Garg HG, Quinn DA, Homer RJ, Goldstein DR, Bucala R, Lee PJ, Medzhitov R, Noble PW (2005) Regulation of lung injury and repair by Tolllike receptors and hyaluronan. Nat Med 11:1173-1179. CrossRef Medline Jiang D, Liang J, Noble PW (2011) Hyaluronan as an immune regulator in human diseases. Physiol Rev 91:221-264. CrossRef Medline

Jones LL, Liu Z, Shen J, Werner A, Kreutzberg GW, Raivich G (2000) Regulation of the cell adhesion molecule CD44 after nerve transection and direct trauma to the mouse brain. J Comp Neurol 426:468-492. CrossRef Medline

Joseph EK, Chen X, Bogen O, Levine JD (2008) Oxaliplatin acts on IB4positive nociceptors to induce an oxidative stress-dependent acute painful peripheral neuropathy. J Pain 9:463-472. CrossRef Medline

Juhlin L (1997) Hyaluronan in skin. J Intern Med 242:61-66. CrossRef Medline

Kaaijk P, Pals ST, Morsink F, Bosch DA, Troost D (1997) Differential expression of CD44 splice variants in the normal human central nervous system. J Neuroimmunol 73:70-76. CrossRef Medline

Kataoka Y, Ariyoshi W, Okinaga T, Kaneuji T, Mitsugi S, Takahashi T, Nishihara T (2013) Mechanisms involved in suppression of ADAMTS4 expression in synoviocytes by high molecular weight hyaluronic acid. Biochem Biophys Res Commun 432:580-585. CrossRef Medline

Khasabov SG, Rogers SD, Ghilardi JR, Peters CM, Mantyh PW, Simone DA (2002) Spinal neurons that possess the substance $P$ receptor are required for the development of central sensitization. J Neurosci 22:9086-9098. Medline

Khasar SG, McCarter G, Levine JD (1999) Epinephrine produces a betaadrenergic receptor-mediated mechanical hyperalgesia and in vitro sensitization of rat nociceptors. J Neurophysiol 81:1104-1112. Medline

Khomula EV, Ferrari LF, Araldi D, Levine JD (2017) Sexual dimorphism in a reciprocal interaction of ryanodine and IP3 receptors in the induction of hyperalgesic priming. J Neurosci 37:2032-2044. CrossRef Medline

Komori K, Nonaka T, Okada A, Kinoh H, Hayashita-Kinoh H, Yoshida N, Yana I, Seiki M (2004) Absence of mechanical allodynia and Abeta-fiber sprouting after sciatic nerve injury in mice lacking membrane-type 5 matrix metalloproteinase. FEBS Lett 557:125-128. CrossRef Medline

Kozai T, Yamanaka H, Dai Y, Obata K, Kobayashi K, Mashimo T, Noguchi K 
(2007) Tissue type plasminogen activator induced in rat dorsal horn astrocytes contributes to mechanical hypersensitivity following dorsal root injury. Glia 55:595-603. CrossRef Medline

Lamb RF, Hennigan RF, Turnbull K, Katsanakis KD, MacKenzie ED, Birnie GD, Ozanne BW (1997) AP-1-mediated invasion requires increased expression of the hyaluronan receptor CD44. Mol Cell Biol 17:963-976. CrossRef Medline

Landowne D (1993) Measuring nerve excitation with polarized light. Jpn J Physiol 43 [Suppl 1]:S7-S11.

Lesley J, Hascall VC, Tammi M, Hyman R (2000) Hyaluronan binding by cell surface CD44. J Biol Chem 275:26967-26975. CrossRef Medline

Li L, Wang B, Gao T, Zhang X, Hao JX, Vlodavsky I, Wiesenfeld-Hallin Z, Xu XJ, Li JP (2012) Heparanase overexpression reduces carrageenaninduced mechanical and cold hypersensitivity in mice. Neurosci Lett 511: 4-7. CrossRef Medline

Litwiniuk M, Krejner A, Speyrer MS, Gauto AR, Grzela T (2016) Hyaluronic acid in inflammation and tissue regeneration. Wounds 28:78-88. Medline

Louderbough JM, Schroeder JA (2011) Understanding the dual nature of CD44 in breast cancer progression. Mol Cancer Res 9:1573-1586. CrossRef Medline

Mabuchi K, Tsukamoto Y, Obara T, Yamaguchi T (1994) The effect of additive hyaluronic acid on animal joints with experimentally reduced lubricating ability. J Biomed Mater Res 28:865-870. CrossRef Medline

McKee CM, Penno MB, Cowman M, Burdick MD, Strieter RM, Bao C, Noble PW (1996) Hyaluronan (HA) fragments induce chemokine gene expression in alveolar macrophages: the role of HA size and CD44. J Clin Invest 98:2403-2413. CrossRef Medline

Meran S, Luo DD, Simpson R, Martin J, Wells A, Steadman R, Phillips AO (2011) Hyaluronan facilitates transforming growth factor- $\beta 1$-dependent proliferation via CD44 and epidermal growth factor receptor interaction. J Biol Chem 286:17618-17630. CrossRef Medline

Mizrahy S, Raz SR, Hasgaard M, Liu H, Soffer-Tsur N, Cohen K, Dvash R, Landsman-Milo D, Bremer MG, Moghimi SM, Peer D (2011) Hyaluronan-coated nanoparticles: the influence of the molecular weight on CD44-hyaluronan interactions and on the immune response. J Control Release 156:231-238. CrossRef Medline

Monzon ME, Fregien N, Schmid N, Falcon NS, Campos M, CasalinoMatsuda SM, Forteza RM (2010) Reactive oxygen species and hyaluronidase 2 regulate airway epithelial hyaluronan fragmentation. J Biol Chem 285:26126-26134. CrossRef Medline

Morrison H, Sherman LS, Legg J, Banine F, Isacke C, Haipek CA, Gutmann DH, Ponta H, Herrlich P (2001) The NF2 tumor suppressor gene product, merlin, mediates contact inhibition of growth through interactions with CD44. Genes Dev 15:968-980. CrossRef Medline

Muto J, Yamasaki K, Taylor KR, Gallo RL (2009) Engagement of CD44 by hyaluronan suppresses TLR4 signaling and the septic response to LPS. Mol Immunol 47:449-456. CrossRef Medline

Nakamura K, Yokohama S, Yoneda M, Okamoto S, Tamaki Y, Ito T, Okada M, Aso K, Makino I (2004) High, but not low, molecular weight hyaluronan prevents T-cell-mediated liver injury by reducing proinflammatory cytokines in mice. J Gastroenterol 39:346-354. CrossRef Medline

Nishiguchi J, Sasaki K, Seki S, Chancellor MB, Erickson KA, de Groat WC, Kumon H, Yoshimura N (2004) Effects of isolectin B4-conjugated saporin, a targeting cytotoxin, on bladder overactivity induced by bladder irritation. Eur J Neurosci 20:474-482. CrossRef Medline

Orian-Rousseau V, Sleeman J (2014) CD44 is a multidomain signaling platform that integrates extracellular matrix cues with growth factor and cytokine signals. Adv Cancer Res 123:231-254. CrossRef Medline

Padmanabhan J, Gonzalez AL (2012) The effects of extracellular matrix proteins on neutrophil-endothelial interaction: a roadway to multiple therapeutic opportunities. Yale J Biol Med 85:167-185. Medline

Parada CA, Yeh JJ, Joseph EK, Levine JD (2003a) Tumor necrosis factor receptor type-1 in sensory neurons contributes to induction of chronic enhancement of inflammatory hyperalgesia in rat. Eur J Neurosci 17:18471852. CrossRef Medline

Parada CA, Yeh JJ, Reichling DB, Levine JD (2003b) Transient attenuation of protein kinase Cepsilon can terminate a chronic hyperalgesic state in the rat. Neuroscience 120:219-226. CrossRef Medline

Pesarrodona M, Ferrer-Miralles N, Unzueta U, Gener P, Tatkiewicz W, Abasolo I, Ratera I, Veciana J, Schwartz S Jr, Villaverde A, Vazquez E (2014) Intracellular targeting of $\mathrm{CD} 44^{+}$cells with self-assembling, protein only nanoparticles. Int J Pharm 473:286-295. CrossRef Medline

Piotrowicz RS, Damaj BB, Hachicha M, Incardona F, Howell SB, Finlayson M
(2011) A6 peptide activates CD44 adhesive activity, induces FAK and MEK phosphorylation, and inhibits the migration and metastasis of CD44expressing cells. Mol Cancer Ther 10:2072-2082. CrossRef Medline

Quanhong Z, Ying X, Moxi C, Tao X, Jing W, Xin Z, Li W, Derong C, Xiaoli $Z$, Wei J (2012) Intrathecal PLC $(\beta 3)$ oligodeoxynucleotides antisense potentiates acute morphine efficacy and attenuates chronic morphine tolerance. Brain Res 1472:38-44. CrossRef Medline

Raber J, Olsen RH, Su W, Foster S, Xing R, Acevedo SF, Sherman LS (2014) CD44 is required for spatial memory retention and sensorimotor functions. Behav Brain Res 275:146-149. CrossRef Medline

Radin EL, Swann DA, Weisser PA (1970) Separation of a hyaluronate-free lubricating fraction from synovial fluid. Nature 228:377-378. CrossRef Medline

Randall LO, Selitto JJ (1957) A method for measurement of analgesic activity on inflamed tissue. Arch Int Pharmacodyn Ther 111:409-419. Medline

Ries A, Goldberg JL, Grimpe B (2007) A novel biological function for CD44 in axon growth of retinal ganglion cells identified by a bioinformatics approach. J Neurochem 103:1491-1505. CrossRef Medline

Ruppert SM, Hawn TR, Arrigoni A, Wight TN, Bollyky PL (2014) Tissue integrity signals communicated by high-molecular weight hyaluronan and the resolution of inflammation. Immunol Res 58:186-192. CrossRef Medline

Saloman JL, Scheff NN, Snyder LM, Ross SE, Davis BM, Gold MS (2016) Gi-DREADD expression in peripheral nerves produces ligand-dependent analgesia, as well as ligand-independent functional changes in sensory neurons. J Neurosci 36:10769-10781. CrossRef Medline

Scroggs RS, Fox AP (1992a) Calcium current variation between acutely isolated adult rat dorsal root ganglion neurons of different size. J Physiol 445:639-658. CrossRef Medline

Scroggs RS, Fox AP (1992b) Multiple $\mathrm{Ca}^{2+}$ currents elicited by action potential waveforms in acutely isolated adult rat dorsal root ganglion neurons. J Neurosci 12:1789-1801. Medline

Senbanjo LT, Chellaiah MA (2017) CD44: a multifunctional cell surface adhesion receptor is a regulator of progression and metastasis of cancer cells. Front Cell Dev Biol 5:18. CrossRef Medline

Shin T, Ahn M, Kim H, Moon C, Kang TY, Lee JM, Sim KB, Hyun JW (2005) Temporal expression of osteopontin and CD44 in rat brains with experimental cryolesions. Brain Res 1041:95-101. CrossRef Medline

Singleton PA, Bourguignon LY (2002) CD44v10 interaction with Rhokinase (ROK) activates inositol 1,4,5-triphosphate (IP3) receptormediated $\mathrm{Ca}^{2+}$ signaling during hyaluronan (HA)-induced endothelial cell migration. Cell Motil Cytoskeleton 53:293-316. CrossRef Medline

Singleton PA, Bourguignon LY (2004) CD44 interaction with ankyrin and IP3 receptor in lipid rafts promotes hyaluronan-mediated $\mathrm{Ca}^{2+}$ signaling leading to nitric oxide production and endothelial cell adhesion and proliferation. Exp Cell Res 295:102-118. CrossRef Medline

Snider WD, McMahon SB (1998) Tackling pain at the source: new ideas about nociceptors. Neuron 20:629-632. CrossRef Medline

Soleman S, Filippov MA, Dityatev A, Fawcett JW (2013) Targeting the neural extracellular matrix in neurological disorders. Neuroscience 253:194213. CrossRef Medline

Song MJ, Wang YQ, Wu GC (2009) Additive anti-hyperalgesia of electroacupuncture and intrathecal antisense oligodeoxynucleotide to interleukin-1 receptor type I on carrageenan-induced inflammatory pain in rats. Brain Res Bull 78:335-341. CrossRef Medline

Sretavan DW, Feng L, Puré E, Reichardt LF (1994) Embryonic neurons of the developing optic chiasm express L1 and CD44, cell surface molecules with opposing effects on retinal axon growth. Neuron 12:957-975. CrossRef Medline

Stern R, Asari AA, Sugahara KN (2006) Hyaluronan fragments: an information-rich system. Eur J Cell Biol 85:699-715. CrossRef Medline

Stucky CL, Lewin GR (1999) Isolectin B(4)-positive and -negative nociceptors are functionally distinct. J Neurosci 19:6497-6505. Medline

Su L, Wang C, Yu YH, Ren YY, Xie KL, Wang GL (2011) Role of TRPM8 in dorsal root ganglion in nerve injury-induced chronic pain. BMC Neurosci 12:120. CrossRef Medline

Summer GJ, Romero-Sandoval EA, Bogen O, Dina OA, Khasar SG, Levine JD (2008) Proinflammatory cytokines mediating burn-injury pain. Pain 135:98-107. CrossRef Medline

Sun JL, Xiao C, Lu B, Zhang J, Yuan XZ, Chen W, Yu LN, Zhang FJ, Chen G, Yan M (2013) CX3CL1/CX3CR1 regulates nerve injury-induced pain 
hypersensitivity through the ERK5 signaling pathway. J Neurosci Res 91: 545-553. CrossRef Medline

Taiwo YO, Levine JD (1989) Prostaglandin effects after elimination of indirect hyperalgesic mechanisms in the skin of the rat. Brain Res 492:397399. CrossRef Medline

Taiwo YO, Levine JD (1991) Further confirmation of the role of adenyl cyclase and of cAMP-dependent protein kinase in primary afferent hyperalgesia. Neuroscience 44:131-135. CrossRef Medline

Taiwo YO, Coderre TJ, Levine JD (1989) The contribution of training to sensitivity in the nociceptive paw withdrawal test. Brain Res 487:148-151. CrossRef Medline

Tajerian M, Clark JD (2015) The role of the extracellular matrix in chronic pain following injury. Pain 156:366-370. CrossRef Medline

Tammi R, MacCallum D, Hascall VC, Pienimäki JP, Hyttinen M, Tammi M (1998) Hyaluronan bound to CD44 on keratinocytes is displaced by hyaluronan decasaccharides and not hexasaccharides. J Biol Chem 273: 28878-28888. CrossRef Medline

Teriete P, Banerji S, Noble M, Blundell CD, Wright AJ, Pickford AR, Lowe E, Mahoney DJ, Tammi MI, Kahmann JD, Campbell ID, Day AJ, Jackson DG (2004) Structure of the regulatory hyaluronan binding domain in the inflammatory leukocyte homing receptor CD44. Mol Cell 13:483496. CrossRef Medline

Triantaffilidou K, Venetis G, Bika O (2013) Efficacy of hyaluronic acid injections in patients with osteoarthritis of the temporomandibular joint: a comparative study. J Craniofac Surg 24:2006-2009. CrossRef Medline

Underhill C (1992) CD44: the hyaluronan receptor. J Cell Sci 103:293-298. Medline

Unsworth A, Dowson D, Wright V (1975) Some new evidence on human joint lubrication. Ann Rheum Dis 34:277-285. CrossRef Medline

Viatchenko-Karpinski V, Gu JG (2016) Mechanical sensitivity and electrophysiological properties of acutely dissociated dorsal root ganglion neurons of rats. Neurosci Lett 634:70-75. CrossRef Medline

Vierck CJ Jr, Kline RH, Wiley RG (2003) Intrathecal substance p-saporin attenuates operant escape from nociceptive thermal stimuli. Neuroscience 119:223-232. CrossRef Medline
Vistejnova L, Safrankova B, Nesporova K, Slavkovsky R, Hermannova M, Hosek P, Velebny V, Kubala L (2014) Low molecular weight hyaluronan mediated CD44 dependent induction of IL- 6 and chemokines in human dermal fibroblasts potentiates innate immune response. Cytokine 70:97103. CrossRef Medline

Vulchanova L, Olson TH, Stone LS, Riedl MS, Elde R, Honda CN (2001) Cytotoxic targeting of isolectin IB4-binding sensory neurons. Neuroscience 108:143-155. CrossRef Medline

Weisshaar CL, Winkelstein BA (2014) Ablating spinal NK1-bearing neurons eliminates the development of pain and reduces spinal neuronal hyperexcitability and inflammation from mechanical joint injury in the rat. J Pain 15:378-386. CrossRef Medline

Wiley RG, Kline RH, Vierck CJ (2007) Anti-nociceptive effects of selectively destroying substance $\mathrm{P}$ receptor-expressing dorsal horn neurons using [Sar9, Met (O2)11]-substance P-saporin: behavioral and anatomical analyses. Neuroscience 146:1333-1345. CrossRef

Witt M, Kasper M (1998) Immunohistochemical distribution of CD44 and some of its isoforms during human taste bud development. Histochem Cell Biol 110:95-103. CrossRef Medline

Wu PT, Kuo LC, Su FC, Chen SY, Hsu TI, Li CY, Tsai KJ, Jou IM (2017) Highmolecular-weight hyaluronic acid attenuated matrix metalloproteinase-1 and -3 expression via CD44 in tendinopathy. Sci Rep 7:40840. CrossRef Medline

Yamawaki H, Hirohata S, Miyoshi T, Takahashi K, Ogawa H, Shinohata R, Demircan K, Kusachi S, Yamamoto K, Ninomiya Y (2009) Hyaluronan receptors involved in cytokine induction in monocytes. Glycobiology 19: 83-92. CrossRef Medline

Yasuda T (2011) Hyaluronan inhibits Akt, leading to nuclear factor- $\kappa \mathrm{B}$ down-regulation in lipopolysaccharide-stimulated U937 macrophages. J Pharmacol Sci 115:509-515. CrossRef Medline

Zaiden M, Feinshtein V, David A (2017) Inhibition of CD44v3 and CD44v6 function blocks tumor invasion and metastatic colonization. J Control Release 257:10-20. CrossRef Medline 